NBER WORKING PAPER SERIES

\title{
EARLY FERTILITY DECLINE IN THE UNITED STATES: TESTS OF ALTERNATIVE HYPOTHESES USING NEW COMPLETE-COUNT CENSUS MICRODATA AND ENHANCED COUNTY-LEVEL
}

\author{
Michael R. Haines \\ J. David Hacker \\ Matthew S. Jaremski \\ Working Paper 27668 \\ http://www.nber.org/papers/w27668
}
NATIONAL BUREAU OF ECONOMIC RESEARCH
1050 Massachusetts Avenue
Cambridge, MA 02138

August 2020

The authors gratefully acknowledge support from the Minnesota Population Center (P2CHD041023), funded through a grant from the Eunice Kennedy Shriver National Institute of Child Health and Human Development (NICHD). We also wish to thank Ran Abramitzky, Leah Boustan, and Myera Rashid, who published their census crosswalks online for public use. This project was also supported by a research grant from the Eunice Kennedy Shriver National Institute of Child Health and Human Development (R01-HD082120-01Q3). Michael Haines wishes to thank Colgate University for providing research funds from the Banfi Vintners Chair in Economics. The views expressed herein are those of the authors and do not necessarily reflect the views of the National Bureau of Economic Research.

NBER working papers are circulated for discussion and comment purposes. They have not been peerreviewed or been subject to the review by the NBER Board of Directors that accompanies official NBER publications.

(C) 2020 by Michael R. Haines, J. David Hacker, and Matthew S. Jaremski. All rights reserved. Short sections of text, not to exceed two paragraphs, may be quoted without explicit permission provided that full credit, including $\odot$ notice, is given to the source. 
Early Fertility Decline in the United States: Tests of Alternative Hypotheses using New Complete-Count Census Microdata and Enhanced County-Level Data

Michael R. Haines, J. David Hacker, and Matthew S. Jaremski

NBER Working Paper No. 27668

August 2020

JEL No. J13,N21,N31

\section{ABSTRACT}

The U.S. fertility transition in the nineteenth century is unusual. Not only did it start from a very high fertility level and very early in the nation's development, but it also took place long before the nation's mortality transition, industrialization, and urbanization. This paper assembles new county-level, household-level, and individual-level data, including new complete-count IPUMS microdata databases of the 1830-1880 censuses, to evaluate different theories for the nineteenthcentury American fertility transition. We construct cross-sectional models of net fertility for currently-married white couples in census years 1830-1880 and test the results with subset of couples linked between the 1850-1860 and 1860-1870 censuses. We find evidence of marital fertility control consistent with hypotheses as early as 1830. The results indicate support for several different but complementary theories of the early U.S. fertility decline, including the land availability, conventional structuralist, ideational, child demand/quality-quantity trade-off, and life-cycle savings theories.

Michael R. Haines

Department of Economics, 217 Persson Hall

Colgate University

13 Oak Drive

Hamilton, NY 13346

and NBER

MHAINES@MAIL.COLGATE.EDU
Matthew S. Jaremski

Utah State University

Department of Economics and Finance

3565 Old Main Hill

Logan, UT 84322

and NBER

matthew.jaremski@usu.edu

J. David Hacker

University of Minnesota

Department of History

1110 Heller Hall

271 19th Ave S

Minneapolis, MN 55455

hacke010@umn.edu 


\section{Early Fertility Decline in the United States: Tests of Alternative Hypotheses using New Complete- Count Census Microdata and Enhanced County-Level Data}

The fertility transition in the nineteenth-century United States is unusual in a number of respects. The decline comes very early in the nation's development. Between 1800 and 1880, the white population's crude birth rate fell from about 55 to 35 and its total fertility rate fell from about 7.0 to 4.2. In contrast, fertility decline in most western and northern European countries did not commence until circa 1880 (Coale and Watkins 1992). Only France had a comparably early onset of the transition. The U.S. fertility transition also began long before the sustained decline in mortality, which commenced in the 1870s (Haines 1989; Haines 2000). Finally, the transition occurred when the nation was still predominantly agrarian and rural, although the decline in birth rates happened in both rural and urban places. Even in 1880 , only about 28 percent of the U. S. population lived in urban areas (defined by the Census as places with over 2,500 people) and 52 percent of the labor force derived its primary support from non-agricultural activity (Haines and Steckel, 2000, Table 8.1; Carter, et al. 2006, Series Ba829-830).

This article sheds new light on the nineteenth-century fertility transition in the United States by examining correlates of net marital fertility across the period 1830-1880. We rely on several new data sources, including complete-count IPUMS datasets of the 1830, 1840, 1850, 1860,1870 , and 1880 censuses, which document the recent fertility of more than 12 million currently-married white women (Ruggles et al. 2020), and new and enhanced county-level data, which provide important contextual information. These data allow us examine a number of competing, but possibly complementary, explanations for the fertility decline, including the land availability, child demand, life-cycle transition, local labor market/child default, and ideational hypotheses, as well as the conventional structuralist explanation associated with classic demographic transition theory. Ultimately, although the results provide some support for all the tested hypothesis, we find that structural factors emphasized by traditional demographic transition theory (urbanization, occupational structure, education), ideational factors (nativity and church denominations), and child demand theories had a greater substantive impact on married 
women's fertility than the land availability and life-cycle savings theories emphasized in much of the published literature.

Despite the large number of cases available in the complete-count datasets, the data used in this study-like the vast majority of historical data-have limitations. Good instrumental variables are unavailable, omitted variable bias is likely present, and cross-sectional regression coefficients may be biased by endogeneity. Given these limitations, we do not attempt to estimate causal relationships. The datasets assembled here, nonetheless, represent a substantial improvement in quantity, quality, and coverage relative to data used by earlier researchers. The individual-level data allow us to model marital fertility, eliminating the ambiguity in many previous studies as to whether the mechanism linking independent variables to fertility was via changes in the timing and incidence of marriage (a Malthusian adjustment) or via changes in childbearing by married couples (a neo-Malthusian adjustment). We employ state-level fixed effects to control for unobserved spatial heterogeneity and control for a wide variety of economic, demographic, and cultural factors to minimize potential biases. We also test our results with a subset of couples linked between the 1850,1860, and 1870 censuses using preliminary census "crosswalks" recently published by Abramitzky, Boustan and Rashid (2020) that identify the same individuals in multiple censuses. Although these links are preliminary, based only on males, and subject to potential errors, the results largely confirm the findings from the cross-sectional analysis, increasing confidence in the results.

\section{BACKGROUND AND PRIOR STUDIES}

A national birth registration system was not started in the United States until 1915 and not completed until 1933 (Haines 1989). Broad patterns of the nineteenth-century fertility transition, however, are evident in the ratio of the number of children to the number of women of childbearing age reported by decennial censuses. As shown in figure 1, the nation's child-woman ratio (CWR) declined 33 percent between 1800 and 1880. CWRs in urban areas were much lower than CWRs in rural areas in all census years, but urban and rural places experienced similar 
declines from early in the century. New England was the region with the lowest CWRs in each census year and experienced a decline of more than 50 percent over the 80 -year period. CWRs were lower in eastern census regions and higher in western regions, and, to a lesser extent, lower in northern census regions than in southern census regions. ${ }^{1}$

The child-woman ratios shown in figure 1 suggest that fertility rates in the United States at the start of the nineteenth century were high relative to fertility rates in other English-speaking countries. Ansley Coale and Melvin Zelnik estimated that white women surviving their childbearing years in 1800 gave birth to an average of 7.0 children, about 1.6 more children than estimated by historical demographers for women in England and Wales. By 1880, total fertility in the United States had fallen to 4.2, about 0.5 fewer children than in England and Wales (Coale and Zelnik 1963; Woods 2000). Thus, despite a delayed onset of the industrial revolution in the United States relative to England and Wales, the U. S. experienced an earlier onset of the fertility transition.

Explicitly or implicitly, most contemporary observers associated high fertility in the early United States with early and near universal marriage, which was in turn seen as a product of the nation's inexpensive land, abundant resources, and high standard of living. Benjamin Franklin was the first to point out the association of land availability, early marriage, and high fertility:

Land being thus plenty in America, and so cheap as that a labouring Man, that understands Husbandry, can in a short Time save Money enough to purchase a Piece of new Land sufficient for a Plantation, whereon he may subsist a Family; such are not afraid to marry; for if they even look far enough forward to consider how their Children when grown up are to be provided for, they see that more Land is to be had a Rates equally easy, all Circumstances considered...Hence Marriages in America are more general, and more

\footnotetext{
${ }^{1}$ Child-woman ratios plotted in the chart were calculated from the complete-count 1800-1870 complete-count IPUMS census datasets and the 1880 ten-percent IPUMS sample (Ruggles et al. 2020). We adjusted the CWR to account for missing records in a few states in early census years using published results. We also adjusted for differences in reported age groups of children and women using the single year age distribution of the white population in the 1850 complete-count dataset.
} 
generally early, than in Europe (quoted in McCusker and Menard 1985, p. 212).

With the Louisiana Purchase in 1803, the defeat of Indian confederations in the War of 1812 , and the opening of the trans-Appalachian west, land availability may have been near an alltime high in the early nineteenth century. Thereafter, increasing population densities, declining land availability, and rising farm prices-especially in more densely-populated areas near the Atlantic coast and navigable waterways-resulted in a trend toward later marriage, higher proportions who never married, and lower fertility. Imbalanced sex ratios (men outnumbered women in western frontier regions, while women outnumbered men in eastern regions) also contributed to regional differentials in nuptiality and fertility (Haines and Hacker 2011). In a statistical analysis of the 1790-1840 censuses, George Tucker, Professor of Moral Philosophy at the University of Virginia, confirmed a long-term decline in the ratio of children to women in every state between 1800 and 1840 and an inverse relationship between state child-woman ratios and population densities (Tucker 1855, pp. 104-106).

To the extent that the fertility decline was caused by changes in the timing and incidence of marriage, the "early" U.S. fertility decline was not the result of exceptional or innovative behaviors; American marriage patterns were simply converging toward European norms, which in turn caused fertility to decline (Smith 1987). Hacker (2003) has argued that the decline in childwoman ratios prior to 1860 was primarily the result of declining nuptiality. ${ }^{2}$ Likewise, state and regional differentials in child-woman ratios observed by Tucker and analyzed by subsequent researchers likely reflected differentials in the timing and incidence of marriage (Hacker 2008). ${ }^{3}$ Beginning in early the nineteenth century, however, observers suggested that regional

\footnotetext{
${ }^{2}$ Increased mortality in the late antebellum period also contributed to declining child-woman ratios (Hacker 2003; 2010).

3 In a separate county-level analysis, we found evidence that adjustments in nuptiality played a major role in the decline in child-woman ratios and cross-sectional differentials in child-woman ratios, especially in the early stages of the decline. [BLINDED CITATION].
} 
differentials in the "productivity" of marriages resulted from differentials in the practice of conscious family limitation strategies. In an earlier essay, Tucker (1827) mentioned a secret "long practised by many in the east" that allowed couples to control fertility without abstinence. Private secrets were made public in the early 1830s, when Charles Knowlton and Robert Dale Owen separately published books describing methods of contraception (Knowlton recommended douching with spermicides while Owen recommended the practice of coitus interuptus). Although Knowlton was arrested and found guilty of publishing an obscene work and sentenced to three months hard labor, public demand created a rapidly growing market for contraceptive advice and goods by the mid nineteenth century (Brodie 1994).

Unfortunately, early studies based on county-level child-woman ratios could not distinguish between the effects of nuptiality and marital fertility control. Yasuba (1962), Forster, Tucker, and Bridge (1972), Easterlin (1976), and Sundstrom and David (1988) suggested a variety of explanations for the unique American fertility transition, some of which required the conscious practice of birth control by married couples and some of which likely operated through adjustments in nuptiality. Because the nation was overwhelmingly rural and dominated by the agricultural sector of the economy, most explanations focused on the changing costs and benefits of farm children. A leading candidate has been the land availability hypothesis, which grew out of the observed and consistent negative correlation between child-woman ratios and population density. Originally proposed by Yasuba using state-level data, the conclusion was strengthened through the examination of agricultural land availability by county by Forster, Tucker, and Bridge.

The land availability hypothesis has three potential mechanisms. The first mechanism is a simple Malthusian check on marriage, which in turn affected fertility. Family formation in nineteenth-century American was "neolocal," with young couples setting up a new household upon marriage rather than living as dependents in a parent's or sibling's household (Smith 1993). Increasing population densities lowered land availability, increased the price of viable farms, and caused young couples to delay marriage in order to acquire the necessary resources to purchase a viable farm and set up a new household (Yasuba 1962, 159; Haines 1996; Hacker 2008). 
A second mechanism is old age insurance through the intergenerational bequest process. As farmers are almost completely dependent on their farm for income, they have little or no income to support themselves when they stop working due to old age or injury. Therefore, parents might decide to transfer real property (that is, actual or potential farm sites) to children in order to keep the children working the farm or another nearby farm and supporting them when they retire. Essentially having children was a form of old age support in the rural, agrarian environment. At the same time, parents might have adjusted fertility in an altruistic motive of wanting to provide adequate farmsteads for their children. Greater availability of land in an area would keep the price of land low and make it easier for a parent to obtain additional nearby farms for their surviving children, who could continue working the farm. Future-minded couples with a targeted bequest in mind could adjust their fertility in response to growing land scarcity and higher prices (Easterlin, Alter, and Condran 1978).

The third mechanism by which land availability affects fertility is through labor availability. Farm work is hard and requires tremendous numbers of labor hours. On the frontier where labor is scarce, farmers might have additional children in order to have more help in the fields (Craig 1993). Microdata from the 1860 Northern Farms Sample (Bateman and Foust 1974; Easterlin 1976; Easterlin, Alter, and Condran 1978) show that the gradient of fertility from the longest settled areas to the frontier was positive but not monotonic. Children were less valuable on the frontier where adult labor was needed to clear land, but once an area had been settled, children were needed to work the farm. Thus, on the immediate frontier, households were small (often just a single male) but just inside the frontier they were large (Leet 1976).

Another explanation of the decline in fertility is the rise in other alternatives for children, notably non-agricultural employment in growing urban centers. Put forward in the form of an inter-generational bargaining model by Sundstrom and David (1988), this hypothesis embodies the notion that parents were seeking to reduce the risk of child default (i.e., children moving far enough away so as to be unable to provide old age care for the parents). The authors argued that a more favorable ratio of non-agricultural to agricultural wages in a region led to a higher risk that 
children would leave the area and not take care of their parents. Parents thus would have to adapt by paying a larger "bribe" in terms of property, both real and financial. Given that farmers had scarce resources and could not easily grow the total value of the inheritance, a larger share would likely have been created by reducing the number of recipients (i.e., smaller families). Although Sundstrom and David pose this as an alternative to the land availability hypothesis, it seems a complement rather than a substitute for the traditional theory.

In addition to stressing the importance of land availability, research on the U.S. fertility decline has emphasized traditional structural variables from classic demographic transition theory (e.g., urbanization, industrialization, education, women's work outside the home, etc.), especially in the period after the Civil War (1861-65), when urbanization, industrialization and school attendance accelerated (Guest 1981; Guest and Tolnay 1983; Wanamaker 2012). Notestein's classic 1953 article concisely summarizes many potential causes:

The new ideal of the small family arose typically in the urban industrial society. It is impossible to be precise about the various causal factors, but apparently many were important. Urban life stripped the family of many functions in production, consumption, recreation, and education. In factory employment the individual stood on his own accomplishments. The new mobility of young people and the anonymity of city life reduced the pressure toward traditional behavior exerted by the family and community. In a period of rapidly developing technology, new skills were needed, and new opportunities for individual advancement arose. Education and a rational point of view became increasingly important. As a consequence the cost of child-rearing grew and the possibilities for economic contributions by children declined. Falling death-rates at once increased the size of the family to be supported and lowered the inducements to have many births. Women, moreover, found new independence from household obligations and new economic roles less compatible with childbearing.

More recent economic theory has emphasized changing demand for children in the context of rising family incomes and the cost of children relative to other goods (Easterlin and Crimmins 1985). Most evidence suggests that fertility and income were positively correlated prior to the fertility transition. Economic changes related to industrialization and urbanization, however, led to an increase in the demand for child "quality" - which required greater parental investments in 
education and associated declines in child labor-at the expense of child "quantity," helping to explain why fertility declined during a period or rising incomes and why fertility was inversely correlated with income from at least the latter half of the nineteenth century (Becker 1981; Jones and Tertilt 2008; Becker et al. 2010; Dribe, Oris, and Pozzi 2014).

There has also been interest in the ideational view of fertility transition (e.g., Lesthaeghe 1980,$1983 ;$ Smith 1987). This view-which grew out of the finding that European nations at different levels of socio-economic development (e.g. levels of urbanization, share of nonagricultural employment in the labor force, and levels of literacy) commenced their irreversible fertility transitions within a short period of time in relation to one another (Knodel and van de Walle 1979)-argues that the growing influence and diffusion of secular values has changed people's willingness to control and plan family size. Smith (1987) proposed that greater adherence to religious denominations that encouraged greater individualism in the nineteenth century (Unitarian, Universalist, Congregational and some Presbyterians) resulted in earlier and more rapid fertility declines, which has received confirmation in more recent county-level analyses (Haines and Hacker 2011). In addition, Hacker $(1999,2016)$ and Hacker and Roberts $(2017,2019)$ have documented a positive correlation between couples' choices of biblical versus secular names for their children and marital fertility, and large differentials in fertility between the native-born and foreign born populations, all else being equal, suggesting that religion and culture played significant roles in the U. S. fertility transition.

Another perspective looks at the life-cycle savings hypothesis (Carter, Ransom, and Sutch 2004). Building on the original work of Modigliani (e.g., 1966), the hypothesis argues that individuals have to provide for their old age whether that be through children, real assets, or financial assets. When there are limited financial options and in a largely rural, agrarian setting, such as the United States in the early nineteenth century, couples will choose children and, if possible, real assets such as land, structures, and livestock. As the financial network broadens and deepens, however, financial saving becomes more feasible and attractive, reducing the incentives for having children as insurance for old age. Knodel (1974, pp. 232-36), for example, found fertility 
in nineteenth-century Germany's administrative districts was inversely correlated with the number of bank accounts per capita. Financial savings also are largely independent of the risk of child default and increases in land prices. For instance, as land becomes more expensive, the best land is taken up, and local non-agricultural labor markets develop in towns and cities, child default becomes a greater risk and other alternatives must be sought. ${ }^{4}$

Three studies have discussed the effects of banks on fertility differentials in the United States. Steckel (1992) included banking data in a panel study of 638 rural families linked between the 1850 and 1860 censuses. The results suggested that the development of the nation's financial system-as proxied by the number of banks per capita in couples' states of residence-was the most important factor associated with differentials in couples' net marital fertility between the two censuses. The number of banks were capita has higher in states in the Northeast, where marital fertility rates were lower, and lower in states in the South and near the western frontier, where marital fertility rates were highest. The results supported the hypothesis that banks provided couples the option of accumulating financial assets as means of providing for their oldage support rather than investing in children. The results also indirectly supported the hypothesis that the development of banking was an important factor in the fertility transition. In 1811 , there were only 1.45 banks per 100,000 white residents; by 1840, the rate had more than quadrupled. The second study, by Carter, Ransom and Sutch (2004), looked at counties in the entire U.S. in 1840 and found support for the idea that life-cycle determinants were beginning to dominate over the traditional reliance on large numbers of children for old-age security. By out-migrating to the frontier, children were "defaulting" on their obligation to support their parents in old age and driving prospective parents to increase savings and investments in banks, financial markets and insurance. The authors, however, included no measures of banks or financial markets in their regressions to test the hypothesis directly. A third study by Basso and Cuberes (2013) found a

\footnotetext{
${ }^{4}$ It is important to note that bank default was also a risk during the period, suggesting that a combination of investments might be optimal for families.
} 
robust and consistent inverse relationship between the white child-woman ratio and the presence of one or more banks for a limited set of 270 mostly Northeastern counties in 1840.

\section{DATA AND RESULTS}

We rely on new, complete-count IPUMS microdata for census years 1830-1870 and the 10percent density 1880 IPUMS sample (Ruggles et al. 2020) to test alternative hypotheses. These data document the recent marital fertility of approximately 12 million currently-married white couples. Each dataset includes individual- and household-level variables (e.g., occupation, literacy, nativity, wealth, urban/rural location, etc.) that can be included in empirical models of fertility. ${ }^{5}$ We linked these data with contextual information collected for each of the nation's counties in each census year, which allows us to construct more comprehensive tests of leading theories. The number of counties with valid data increased from 946 in 1830 to 2,454 in 1880, providing a rich contextual database. We supplemented existing public-use county-level datasets (ICPSR 2010 and 2014) with new measures of each county's agriculture and manufacturing (1840-1880), the availability of water and/or railroad connections (1840-1860), and data on churches (1850-1870). Most importantly for our examination of the banking/life-cycle savings hypothesis, we added county-level data on the number of banks and the size of their deposits in each census year using data from Warren Weber's antebellum bank census database $(2005,2008)$ and from the Merchants and Bankers' Directory.

We limited our analytical dataset to currently-married white women age 15-49 with spouses present in the household. The white population comprised approximately 85 percent of the total population of the United States in the nineteenth century. Unfortunately, minimal data are available for the nation's black population until the 1870 census, preventing the imputation of currently-married black couples and their number of children in most census years. Other studies

\footnotetext{
${ }^{5}$ At the time of our analysis, the 1880 complete-count IPUMS dataset lacked the variables literacy and schooling, forcing us to rely on the 10 percent sample.
} 
have shown little indication of fertility decline in the black population until after circa 1880, when the total fertility rate for the black population was 7.26 (Tolnay 1981), suggesting that marital fertility decline in the period $1830-1880$ was for the most part limited to the white population.

For each census year, we constructed cross-sectional models of fertility, using the number of couples' coresident own children age $0-4$ at the time of the census as the dependent variable. By relying on a measure of marital fertility, we can be reasonably certain that identified covariates operated via couples' conscious control of their fertility. In contrast, covariates associated with general measures of fertility, such as county-level child-woman ratios, may have operated via the Malthusian mechanism of nuptiality. Because it is a count of living children, the dependent variable is a measure of couples' recent "net" marital fertility (the number of live births in the previous five years less the number of those children who died before the census). To a small extent, differentials in net marital fertility will reflect differentials in child mortality. We do not expect child mortality to be significant source of bias for several reasons, however. First, nineteenth-century life tables (Hacker 2010) indicate that a large majority (approximately 80 percent) of white children born in the five years prior to the $1830-1880$ censuses survived to be counted by the census. Large differentials in child mortality will therefore result in small differentials in net fertility. Second, biases resulting from differentials in child mortality will be controlled to some extent by our use of state fixed effects and inclusion of urban/rural residence and size of city variables in our models, which have been found to be among the most important correlates of child mortality (Preston and Haines 1991). Recent studies of early twentieth century Sweden and the United States (Scalone and Dribe 2017; Hacker 2020), when child mortality differentials were large, indicate that results of net marital fertility models closely mirror those of marital fertility models. Finally, we observe that the fertility transition clearly resulted in a decline in the number of surviving children, not just the number of children born. To the extent that couples adjusted their child bearing in response to the number of their surviving children rather than their number of live births, net marital fertility may be a preferable measure (Dribe et al. 
2016). Nonetheless, we consider the possible influence of differentials in child mortality in our discussion.

Our datasets include a large number of suspected correlates of marital fertility, which allows us to construct comprehensive tests of the hypotheses discussed above. Where available, we include each mother's age group and labor force participation; father's occupation group and age differential from spouse; and couple's real and personal estate wealth, slave ownership, literacy, nativity, and residence type (urban/rural and size of city). Because husbands and wives' place of birth and literacy were strongly inter-correlated, we coded nativity and literacy as couplelevel variables. If one spouse was native born and one foreign born, we coded the couple as being foreign born. We considered a couple as being literate only if both the husband and wife could read and write. At the county level, we used average school attendance, farm values per acre, proportion of farm acreage improved, proportion of church seating capacities in liberal/pietistic churches, presence of rail or canal transportation, and the number of banks. ${ }^{6}$

We relied on a standard OLS regression because of its ease of interpretation. Although the dependent variable is a count with no negative values and includes many observations of zero children, suggesting the need of Poisson regression or other count-based regression approach to ensure unbiased standard errors, we have complete microdata with hundreds of thousands of observations in each census year. We compared results using both OLS and Poisson approaches and found the vast majority of variables were statistically significant at the 0.001 level in all models. We employed state-level fixed effects in all models to control for unobserved heterogeneities among couples residing in different states.

Because the availability of variables varies across censuses, we present two empirical models in each year: a parsimonious model, which includes only the variables present in all census years shown in the table, and a full model, which uses all the variables available in a given year.

\footnotetext{
${ }^{6}$ Because the farm values per acre were skewed by a few counties with very high values, we logged the variables to reduce the influence of outliers.
} 
The parsimonious specifications allow us to determine whether the factors are important before controlling for other variables and gives a better view of how their effects changed over time. The augmented specifications effectively controls for many other factors that could have been driving fertility and should present a more effective lower bound on the coefficients, but at some cost to comparability across time.

For all census years other than 1880, when marital status and relationship to household head were first recorded in the census, we identified currently-married couples and their number of children using logical rules and variables constructed by the IPUMS project. Unfortunately, the way each census was conducted did not allow us to use consistent imputation procedures for all six censuses, forcing us to conduct our analysis in two parts. We first present the results for the 1830 and 1840 censuses, which were conducted at the household level, and then the results for the 1850-1880 censuses, which were conducted at the individual level (Ruggles and Magnuson 2020). For the 1830 and 1840 analysis, we restricted the dataset to what we call "imputed nuclear households" containing only one woman of childbearing age and one potential spouse. To evaluate how this restriction may have influenced the results, we include the 1850 census in both sets of analyses.

\section{Cross-Sectional Analysis, 1830-1850}

Prior to 1850, censuses were conducted on a household level. In 1840, census enumerators recorded information for all individuals in enumerated households on a single line of a two-sided schedule with 80 summary columns (e.g., the number of white males age 0-4 in the household, the number of white females age 15-19 in the household, the number of household members engaged in agriculture, etc.). No information was collected on the family relationships or marital statuses of individuals in the household. As a result, it is difficult-and in many cases impossible-to determine whether households contained one or more married couples or to determine the number of own children each couple had in the household.

Our approach to using the 1830 and 1840 complete-count datasets was to limit the 
analytical dataset to households that contained one (and only one) white female age 15-49 and one (and only one) white male age 15-59 in either the same age group as the woman or in the next older age group (e.g., a household with one white female age 30-39 and one white male age 4049). ${ }^{7}$ If a household contained more than one woman or more than one man of childbearing ages or if the two age groups were not compatible with a probable married couple (e.g., a household with one white female age 30-39 and one white male age 20-29), we dropped the household from the analysis. We also dropped all households with one or more females age 50 and above and one or more males age 60 and above to avoid ambiguity with other variables measured at the household level (e.g., number of illiterate individuals). With these selection criteria, however, we can be reasonably confident that selected households contained a married couple and that all coresident children less than age 5 in the household were children of the couple. Hereafter we refer to these households as "imputed nuclear households," whether or not they contained any children. ${ }^{8}$

To determine the potential impact of these restrictions and the accuracy of our imputations of married couples, we collapsed the individual-level 1850 IPUMS dataset to a onerecord household summary and used the same logical rules to impute nuclear households used with the 1830 and 1840 datasets. We also replicated, as closely as possible, the household-level variables available in 1830 and 1840. The exercise indicated that our approach results in a significant loss in the number of married couples. With access to all individual-level data, we could identify 2,590,117 currently-married women age 15-49 with spouses present in the 1850 census. When we collapsed the dataset to a household-level summary and used the same logical rules as

\footnotetext{
7 The censuses counted the number of individuals of each sex in five-year age groups through age group 15-19, and then 10-year groups beginning with 20-29. In our 1850-1880 analysis below, husbands of women age 15-49 were on average 4.5 years older than their wives.

8 IPUMS household-level datasets are also available for census years $1800-1830$. Censuses prior to 1830, however, did not include enough age categories to make similar inferences.
} 
in 1830 and 1840 , the analytical dataset was reduced to 1,124,656 couples, a loss of 57 percent. The rate of loss was much higher among older couples, who were more likely to have own children of childbearing age residing in their households. We also lose a small percentage of households containing multigenerational family members and other types of complex family households as well as a small number of households with husbands in a younger age group than their wives. Our 1830-1850 analysis, therefore, includes a greater proportion of all younger couples as well as lower proportions of all older couples and couples living in complex family arrangements than our 1850-1880 analysis. On the other hand, our restrictions and rules resulted in a high level of accuracy among the couples selected and in our measurement of marital fertility. Just $1.1 \%$ of our imputed nuclear households in 1850 did not contain a currently-married couple identified by the IPUMS project.

Table 1 presents the results for the parsimonious models using only variables available in 1830, 1840, and 1850, while Table 2 shows the full model results using all available variables. To increase comparability of each variable's substantive impact across time, we divided coefficients in each census year by the mean number of children age 0-4 in the household (shown at the bottom of the table) and multiplied by 100 . For categorical and dummy variables, such as transportation and the number of banks, the results indicate the percentage difference in children age 0-4 relative to the reference category. For other independent variables, the results indicate the percentage change in the number of children to a one-unit change in the variable. Results, of course, will depend on the choice of reference category and the scale used to measure real variables, which we have chosen to allow the precision of the results to show.

We included the age group of the childbearing woman in all models. Relative to the reference group of women age 20-29, imputed nuclear households containing a female age 30-39 had a modestly greater number of children age 0-4 in all three census years (probably because proportionately more women in the age 20-29 reference group had not been married for the full five-year observation period prior to the census), while those age 40-49 had significantly fewer children (probably the result of lower fecundity at older ages and possibly the increasing practice 
of marital fertility control with age). Relative to 1830, the results in 1840 and 1850 indicate that women's childbearing was more concentrated in their 20 s and less prevalent at older ages, a pattern consistent with the increasing practice of what demographers refer to as "paritydependent fertility control" - the successful attempts by couples to curtail childbearing after reaching a target number of children. This pattern is more evident in the results from the period 1850-1880 discussed below.

We distinguished couples living in urban areas from couples living in rural areas and further categorized urban couples by the population size of their city of residence. The results indicate that couples living in urban areas had fewer children age 0-4 than couples living in rural areas in all three censuses. With only a few exceptions, we find the size of the urban area in which couples resided was negatively correlated with their number of children. This result was likely due in part to higher infant and child mortality in urban areas. Although available data do not allow the measurement of child mortality differentials by size of place in 1830 or 1840, mortality differentials were large in the late nineteenth century when they can first be measured. Children in urban places suffered dramatically higher rates of mortality than children in rural areas, likely because greater crowding and poorer sanitation in cities facilitated the spread of infectious disease (Preston and Haines 1991; Dribe et al. 2020). The large differentials in net marital fertility in 1830 among couples in rural and urban areas, however, strongly suggests that differential child mortality cannot explain the entire difference. ${ }^{9}$

\footnotetext{
${ }^{9}$ All else being equal, child mortality rates in urban areas in the late nineteenth century were between 5-25 percent higher than rates in rural areas, depending on the size of the city (Dribe et al. 2020). If we assume similar differentials in child mortality between rural and urban areas in 1830 and further assume that 80 percent of children born in rural areas in the five years prior to 1830 survived to be counted by the census, couples in urban areas would have 1-6 percent fewer surviving children age 0-4 in 1830 than couples in rural areas given equal numbers of children born.
} 
The presence of one or more banks in a county was negatively correlated with net marital fertility in all three census years. ${ }^{10}$ The dummy variable approach provides a view of both the extensive margin (i.e., the entry of any banks) versus the intensive margin (i.e., the entry of an additional bank). Just getting a bank at all leads to a large negative decline in fertility whether that is the entry of one bank or multiple banks. However, while the coefficients generally show a monotonic decline in the number of children age 0-4 as the number of banks increased, the marginal effect of each extra bank decreases as compared to the county's first bank in most years. These results support of the life-cycle saving hypothesis. ${ }^{11}$

The full models, shown in Table 2, contain a few new insights. Households in 1840 and 1850 with men in professional and commercial occupations had 14-23 percent fewer children under the age of five than the reference group of households with men in agricultural occupations. These results likely reflect differences in the perceived costs and benefits of children. Farm couples

10 We tested and obtained similar results when we included either the logarithm of bank capital (1830-1860 only, using data from Weber 2008) or the logarithm of the number of banks instead of the bank dummies (not shown).

${ }^{11}$ Although we have no reason to believe that fertility decline caused banking to increase, omitted variables in the models potentially associated with bank entry and fertility decline (e.g., industrialization, transportation, and other measures of structural development) may bias the results. Banks were unlikely to start in an extremely rural community without significant economic activity (Atack, Jaremski, and Rousseau 2015). The decision to start a bank, however, was not entirely economic. During the period before the Civil War, banks had to receive a unique charter from their state legislature. As discussed by Hammond (1957) and Bodenhorn (2003), these charters were often related to political interests rather than economic ones. The use of state fixed effects and inclusion of urbanization, therefore, adds some confidence to the results, as does the lack of any large changes in the augmented specifications, which includes additional measures of economic development. 
had greater need for child labor, while professional and commercial couples increasingly invested more in their children's education and benefited less from their labor (Guest 1981; Dribe et al. 2014; Maloney et al. 2014). Providing further support for this theory, school attendance in 1850 was negatively correlated with couples' net marital fertility. Households with men in navigational and manufacturing occupations or with no occupation listed had 2-11 percent fewer children than households with an agricultural occupation listed. The fertility of couples in mining households, which was only modestly lower in 1840 than the fertility couples in agricultural households, was modestly higher in 1850, consistent with studies that have stressed the high-fertility of mining families (e.g., Haines 1977). Mining occupations were rare in the United States, however, accounting for less than one percent of men's occupations in 1840 and 1850 . Overall, these relatively large occupational differences in net marital fertility, consistent with hypothesis about the costs and benefits of childbearing, provides evidence of a significant level of marital fertility control among American couples circa 1835-1840.

The couple-level results show no significant association between households in which one or both members of the couple were foreign born and the number of children 0-4. The result is puzzling, given the finding that the foreign born often had higher birth rates than the native-born population (Spengler, 1930), but the early stages of the mass migrations from Europe in the 1840s undoubtedly had some disruptive effects. Irish migration to the United States in response to the Great Famine (1845-49), in particular, was no doubt associated with lower numbers of surviving children age 0-4 among Irish-born women enumerated by the 1850 census. A couple's literacy was negatively correlated with their fertility, all else being equal. The result, which is typical of results for many other populations across time and place, may reflect an orientation toward greater investments in education and child quality among literate parents, greater exposure to secular culture, or greater access to printed birth control information. The availability of water or railroad transportation was negatively correlated with fertility in 1840 and 1850 . Banks remained negatively correlated with couples' marital fertility in the full models, and the magnitude of the coefficients remain approximately the same, despite the inclusion of additional variables 
associated with economic development, including transportation, school attendance rates, and couples' real estate wealth.

Of special interest to economic theories of fertility decline, including life-cycle savings theory, the 1830 and 1840 censuses included information on slave ownership and the 1850 census included information on real estate wealth. Slaves were a form of personal property and could furnish support in old age. They also performed tasks on farms and plantations (and elsewhere) that children might have been doing in free states. The results indicate that slave ownership was negatively associated with couples' marital fertility. The coefficient was larger for couples with large slave holdings (more than 20 slaves). These results provide support for Carter, Ransom and Sutch's hypothesis (2004) that slaves-who could provide both farm labor and old-age support for aging couples-represented a substitute for investments in child quantity for slaveholding couples. We coded couples' real estate wealth in 1850 into three groups to allow for the possibility on a non-linear relationship with fertility. In all models, including the models for the 1850-1880 regressions below, approximately half of all couples reported no wealth. We chose the minimum dollar value for the high wealth group to yield the upper 10 percent of all couples. Interestingly, we find an inverted $U$-shape relationship between real estate wealth in 1850 and fertility. Couples with no real estate wealth and couples with high real estate wealth had fewer children than the reference group of couples with a moderate level of real estate wealth. We discuss this relationship in more length below with the 1860 and 1870 results, which allow us to include personal estate wealth and the value of local farms per acre for a more comprehensive investigation of the land availability/target bequest hypothesis.

\section{Cross-Sectional Analysis, 1850-1880}

Beginning in 1850, the census recorded each free person's first name, last name, age, sex, race, occupation, literacy (if over age 20), school attendance, and place of birth. Enumerators were instructed to record household members in a specific order, beginning with the household head, followed by the spouse (if present), followed by co-resident children in descending order of age, 
and then other individuals. Dwellings and families were numbered in order of visitation. The IPUMS project took advantage of these enumeration procedures and the available data to construct new variables on family interrelationships, including the relationship of each individual to the household head, the household location of each individuals' mother, father, and spouse, and the total number of each individuals' own children in the household and the number under age five. We relied on the IPUMS variables SPLOC (the location of each individuals' spouse in the household), $A G E, S E X$, and RACE to limit the analytical dataset to currently-married white women age 15-49 with spouses present. We used the IPUMS variable NCHLT5 (number of own children less than age 5 in the household) as the dependent variable.

Tables 3 and 4 shows the results for the parsimonious and full models for the couple-level analysis of the 1850-1880 censuses. Results for the parsimonious models confirm the trend away from higher childbearing rates at older ages discussed above in the 1830-1850 analysis. Relative to women in the age 20-24 reference group, women in all age groups above age 30 experienced lower fertility in each subsequent census from 1850 to 1880 . In 1850, for example, women age 40 44 had 29 percent fewer children age 0-4 in the household than women age 20-24, all else being equal. Thirty years later, in 1880, woman age $40-44$ had 53 person fewer children. The trend is consistent with the increasing practice of parity-dependent control and an associated decline in the mean age at childbearing (Hacker 2003).

Husbands' occupation group was a significant correlate of net marital fertility in all census years, again suggesting that couples perceived different costs and benefits to childbearing depending on the type of labor the husband performed. Similar to the 1840 results, women married to farmers had significantly more children age 0-4 in the household at the time of each census, while women married to men with professional, managerial, clerical and sales occupations had fewer children. The results indicate that occupational differentials widened slightly between 1850 and 1880, suggesting that farm couples lagged non-farm couples in the fertility transition. In 1850, for example, professional couples had 16 percent fewer children than farmers; in 1880, they had 23 percent fewer. Literacy was negatively correlated with fertility at the couple level. 
Differentials between literate and non-literate couples remained consistent between 1850 and 1880, with literate couples having 10-11 percent fewer children than illiterate couples, all else being equal. School attendance was negatively correlated with couples' net marital fertility in all census years. Some of this result may reflect couples' adaptation to compulsory school attendance laws, which were first enacted in Massachusetts in 1852 and which increased costs and decreased the benefits of childbearing. Compulsory attendance laws were rare before 1870 , however, and were typically passed in states that had already obtained high attendance rates (Goldin 1999). To give some since of the substantive impact of schooling on fertility, we calculated the difference in net marital fertility between couples living in a county with one standard deviation unit more children age 5-17 attending school to a couple living in a county with one standard deviation fewer children in school. The results indicate that couples living in areas with more schooling had 6.0 percent fewer children in 1850, 1.5 percent fewer in 1860, 3.8 percent fewer in 1870, and 3.1 percent fewer in 1880.

We coded nativity as a couple-level variable with couples either native born (born in the United States) or born in Germany, Ireland, Great Britain, or other foreign countries. If one partner was native born and the other foreign born, we took the foreign-born birthplace. If both partners were foreign born but born in different countries, we took the birthplace of the wife. In 1850 , the dummy variables for couples' nativity had a relatively modest impact on marital fertility. Couples born in Ireland, for example, had 3 percent more children under age five than native-born couples, all else being equal. In the next three censuses, however, couples' nativities had a greater impact on their childbearing rates than all other variables in the model. In 1860, couples born in Germany had 21 percent more children than native-born white couples, while those born in Ireland at 23 percent more children. Couples born in Great Britain, Canada and other foreign countries also had more children than native-born couples, although the difference was more modest (9-16 percent). By 1880, nativity differentials had widened further, with couples born in Germany having 35 percent more children than native-born couples, couples born in Ireland having 29 percent more children, while those born in Great Britain and Canada had 14-26 percent more. Recent work by 
Hacker and Roberts (2019) confirms that nativity continued to be one of the most substantively important correlates of marital fertility well into the twentieth century, with second generation couples (native born of foreign-born parents) typically having marital fertility rates approximately halfway between those of native-born whites of native parentage and foreign-born populations. Nativity differences - all else being equal-are strong evidence of the importance of culture and ideational factors in determining fertility behaviors. Foreign-born populations clearly lagged behind in the transition to smaller families that accelerated among native-born couples after 1850 , although changes in immigrant selection factors over time may have also played a role in widening fertility differentials.

The 1850-1880 results again confirm that urban places and banks were negatively correlated with marital fertility. Once again, however, lower marital fertility rates among couples in the urban areas (approximately 6-13 percent lower than among rural couples across the models and various size of place dummy variables) likely reflects some differences in infant and child mortality rates, which were undoubtedly higher in urban areas. In most models, there was a consistent gradient in marital fertility among couples living in counties with zero, one, two, three, or four or more banks. The relationships in each census year were remarkably consistent. Increasingly more couples were living in counties with banks or in counties with multiple banks over time, increasing the overall impact of banks. In 1850, 46.8 percent of couples lived in a county without a bank. In 1880, the percentage had fallen to 32.1 percent.

The full models add several variables of interest to fertility decline hypotheses while reducing the potential bias from of omitted variables. Residence in a county with a high proportion of Congregational, Unitarian, Universalist and Presbyterian churches was negatively correlated with marital fertility, supporting hypotheses that members of liberal/individualistic churches were more willing to practice marital fertility control, all else being equal, than members of more conservative churches. As expected, variables typically associated with traditional demographic theory-urbanization, industrialization, education, literacy-were negatively correlated with couples' marital fertility. Couples living in counties with high proportions of the labor force in 
manufacturing had 5-35 percent lower net marital fertility rates, providing some support for local labor market/child default hypotheses. ${ }^{12}$ Beginning with the 1860 census, when it was first measured, married women's participation in the paid labor force was negatively correlated with their fertility, although participation rates were very low (less than 2 percent of married white women in 1870 and 1880 had occupations in paid labor force). The availability of transportation, which was also negatively correlated with couples' net marital fertility in 1840, was negatively correlated in 1850 and 1860, suggesting that residence in a county more connected to the national economy and the movement of goods, people and information was associated with reduced childbearing.

The availability of real estate wealth data in 1850 and real estate and personal estate wealth data in 1860 and 1870 provides a rare opportunity to examine the impact of occupation and wealth simultaneously during the demographic transition (Guinnane 2011). When combined with local farm prices and banking availability, wealth data allow a more comprehensive test of the land availability/target-bequest, banking/life-cycle savings, and child demand/quality-quantity hypotheses than previously possible.

We find inconsistent support for the land availability hypothesis. All else being equal, the theory suggests that couples with low wealth living in counties with high farm prices and high

\footnotetext{
12 Unfortunately, we lack county-level data on the relative wage of laborers and farm hands. In an analysis of child-woman ratios (not shown), we found a negative and statistically significant relationship between the ratio of laborer to farm hand wages in 1850, measured at the state level, and county child-woman ratios. The relationship was positive (the opposite of the expected sign), however, and statistically significant in 1860, providing inconsistent support for Sundstrom and David's hypothesis that a more favorable ratio of non-agricultural to agricultural wages led to greater "default" by farm children to provide old age care of their parents, and a resulting adaptation to this default by parents to limit fertility and provide larger "bribes" to keep children on the farm.
} 
proportions of farm acreage improved would anticipate the greatest difficulty providing nearby farms for their surviving children and would adapt by reducing their fertility relative to couples with high levels of wealth living in counties with low farm prices and low proportions of farm acreage improved. As expected, farm prices and farm acreage improved was negatively correlated with marital fertility in all census years, consistent with the theory. Relative to couples living in counties with farm prices per acre one standard deviation below the mean, couples in counties with farm prices one standard deviation above the mean had 1.0-3.1 percent fewer children, depending on the year. Couples living in counties with a proportion of farm acreage improved one standard deviation above the mean had 2.9-3.9 percent fewer children than couples in counties with farm acreage improved one standard deviation below the mean. ${ }^{13}$ Couples' real estate and personal estate wealth, however, had an inverted u-shaped correlation with fertility. As expected, couples with moderate levels of wealth had higher fertility than couples with no real estate or personal estate wealth, all else being equal. Couples with higher levels of real and personal estate wealth, however, had lower fertility than couples with moderate wealth, despite their ability to provide viable farmsteads nearby for more children. Wealthier couples, of course, may have sought to provide their children with better and more expensive farm bequests reflective of their higher standard of living. Even with higher targeted bequests levels, however, there is little or no reason to expect a negative relationship between wealth and fertility based solely on the land availability thesis. Instead, the results are more consistent with the household economics literature on the quantity-quality tradeoff, which predicts a negative relationship between wealth/income and fertility after income exceeds a threshold where parents' investments in child quality depresses the number of children demanded (Becker 1981; Wahl 1992; Winegarden and Wheeler 1992; Jones and Tertilt 2008). Our occupational results, which show lower fertility rates

\footnotetext{
${ }^{13}$ We have tried other measures of improved acres similar to the approach of Easterlin (1976) with similar results.
} 
among women married to men in higher paying occupation groups, are also consistent with child demand theories. ${ }^{14}$

Results remain consistent with the life-cycle savings hypothesis, which contends that individuals must provide for their old age support by investing in children, real assets, financial assets or slaves. The presence and number of banks were negatively correlated with net marital fertility in each census year. Relative to couples living in counties without banks, couples residing in counties with one or more banks had 2.1-6.3 percent fewer children, all else being equal. Although the cross-sectional approach does not allow us to make causal estimates, the use of state-level fixed effects and large number of variables in the model-especially in census years 1860 and 1870, which included measures of occupation, literacy, personal and real estate wealth, urbanization, transportation, school attendance, farm values, farm acreage improved, and level of manufacturing-increases confidence in findings. Given the agrarian setting and limited financial options in the early nineteenth century, couples invested in children and real estate. In southern census regions prior to 1870, couples also invested in slaves. The expansion of banking and financial networks in the nineteenth-century United States made financial savings more feasible and attractive, reducing the need for couples to rely on children as a source of old-age support. This was especially true of wealthier couples, whose greater real and personal estate wealth

${ }^{14}$ Other researchers (e.g., Jones and Tertilt 2008), have relied on occupational income scores derived from each occupation's average income in 1950 to examine the relationship between fertility and income across time. Although occupational income scores are readily available in the IPUMS datasets, we decided to rely on occupational groups for two reasons. First, we focus on the mid nineteenth century, a century before the association between occupations and their average incomes were established. Given the large structural changes in the economy in that century, there is good reason to suspect large changes in the relative earnings of occupations over time. Second, nearly half of all women in our dataset were married to men with just one occupation, "farmer," who undoubtedly had a large variance in incomes. 
reduced the need to invest in child quantity, and for urban couples. But it was also true of the declining proportion of couples engaged in farming.

Overall, however, the substantive results indicate that banks had a modest impact on marital fertility relative to variables typically associated with traditional demographic transition theory (occupation, urbanization, literacy and schooling) and variables associated with ideational hypotheses (nativity and church denominations). Therefore, while we were able to confirm Steckel's earlier finding (1992) that regional differences in the development of the nation's financial system were an important factor in marital fertility levels, the availability of local banks was not the most important factor by a significant margin. Some of this difference, of course, may reflect differences in the analytical samples and approach; Steckel focused solely on rural couples, who had limited occupational and residential diversity, while our results are based on couples living in rural and urban areas with much greater occupational diversity. Steckel's study was also based on a panel dataset of 638 couples linked across census years while our results are based on cross-sectional analysis. Although results from a panel dataset-to the extent one can be constructed with representative links and a limited number of false positives-are clearly preferable, we do not believe our conclusions are significantly biased by the cross-sectional approach. In the next section, we construct a panel of couples linked between the 1850-1860 and 1860-1870 complete-count censuses using preliminary links recently published by Abramitzky, Boutan and Rashid (2020). Although there are a few modest differences, we find similar results to the cross-sectional analysis, increasing confidence in the results.

\section{Robustness Check Using Preliminary Longitudinal Census Links, 1850-1860 and 1860-1870}

In the last few years, following pioneering research by Joseph Ferrie (1996), economic historians have levered the growth of computational power, new nominal linking algorithms, and restricted-use complete-count census datasets to automatically link individuals across U. S. censuses. The resulting longitudinal datasets have the potential to provide new insights on migration, economic mobility, intergenerational change and many other topics (Goeken et al. 
2011; Feigenbaum 2016; Ruggles, Fitch and Roberts 2018; Abramitzky et al. 2019; Sylvester and Hacker 2020). Unfortunately, most linked datasets are not representative of the general population. Women are typically excluded, as are individuals with common names and inconsistently recorded data. In addition, the potential for Type I errors (incorrectly linking different individuals) and Type II errors (failing to link an individual who appeared in both censuses) to bias results may be significant, depending on the methods used to link individuals and the type of analysis being conducted (Bailey, Cole and Massey 2019).

In early 2020, Abramitzky, Boustan and Rashid published preliminary "crosswalks" identifying males linked between 28 matched pairs of U. S. censuses, including crosswalks for the 1850-1860 and 1860-1870 complete-count IPUMS datasets. Links were made by computer using individuals' first and last names (available only in the restricted-use versions of the IPUMS datasets), sex, race, and birthplace and four variations of the "Abramitzky-Boustan-Eriksson" (ABE) linking procedures, which are based on an Expectation Maximization algorithm that combines age and name distances into a score of the probability that any two records are a true match (Abramitzky et al. 2019).

We relied on the preliminary crosswalks to identify men in our couple-level datasets who were linked between the 1850 and 1860 censuses and men linked between the 1860 and 1870 censuses to create a two panel datasets of married couples. Because women were not linked directly, we restricted the analytical dataset to couples that included a woman whose estimated year of birth (census year minus age at census) was within +/- 2 years in each census. We also took the additional precaution of excluding all women married to men linked to different men with different algorithms. Although we constructed fertility models with each of the four variations on the four ABE linking algorithms, model results varied little. Here we present only the results using the ABE "exact standard" algorithm, which resulted in an analytical dataset of 266,251 couples linked between the 1850 and 1860 censuses and 323,423 couples linked between the 1860 and 1870 censuses. If we ignore the potential for immigration and census under-enumeration to reduce the potentially linkable population in both censuses, these totals represent a linkage rate 
of less than 10 percent of the white couples in the 1860 and 1870 complete-count censuses. We made no attempt to create a weighted sample to correct for group differences in the proportion of individuals linked, but note that the linked dataset includes modestly higher proportions of farm, literate, rural, and high-wealth couples; lower proportions of foreign-born, low-wealth, large-city, Middle Atlantic, and Southern couples; and higher proportions of New England and West North Central region couples compared to the couples in the cross-sectional datasets.

We relied on the same dependent variable (number of own children less than age five) and independent variables in the 1850-1880 cross-sectional models above, but with a few important differences. We measured all independent variables in the first census and the dependent variable in the second census. In addition, we constructed an alternative specification for each panel by including the lagged dependent variable-the number of children age $0-4$ in the previous censusas an independent variable (e.g., for the 1850-1860 panel, independent variables were measured in 1850 , the lagged dependent variable was measured in 1850, and the dependent variable was measured in 1860). The alternative specifications are therefore conditional change models of fertility, which have greater potential to reduce biases caused by omitted variables and endogeneity (Finkel 1995).

The results are shown in Table 5. In general, longitudinal results are consistent with the cross-sectional models. The signs on the coefficients are consistent in almost all cases with the coefficients in the cross-sectional models. The size of the coefficients were typically smaller, however, especially in the conditional change models with the lagged dependent variable included on the right hand side of the equation. Relative to the reference group of women married to farmers, for example, women married to men in professional, managerial and sales occupations had 15-22 percent fewer children in the cross-sectional models, depending on the census year. In the panel datasets, these women had 7-11 percent fewer children. The coefficients associated with urban places of various size were in most cases less than half of their respective sizes in the cross-sectional models. The presence of one or more banks remained negatively associated with marital fertility in the panel datasets, but again the coefficients were noticeably smaller. In the 
conditional change models, the presence of one or more banks was associated with 0.4-1.5 percent fewer children age 0-4 in the census, less than half of the 2.1-5.3 percent fewer children indicated by the 1860 and 1870 cross-sectional results.

For a few variables, the panel results indicated a more substantive impact or a different direction of correlation. School attendance, for example, had a more substantive impact on couples' fertility in the panel dataset than in the cross-sectional models. Interestingly, the u-shape relationship we observed between real and personal estate wealth in the cross-sectional models is not evident in the panel dataset. Instead, there was a consistent negative correlation between wealth and fertility. Relative to the reference group of couples with moderate levels of real and personal estate wealth, couples with no wealth had more children, all else being equal. These results are consistent with the child demand/quality-quantity tradeoff hypothesis and studies reporting a consistent negative relationship between fertility and occupational income (Long and Tertilt 2008). Unfortunately, it is unclear whether the longitudinal results are a less biased indicator of the true relationship between wealth and fertility or a more biased indicator; men with higher levels of wealth were less mobile and linked between censuses in greater proportions than men with no wealth, which may affect the results.

One interpretation for the smaller coefficients in the panel datasets, especially in the models including the lagged dependent variable on the right side of the equation, is that the coefficients based on panel data are less subject to endogeneity and omitted variable bias than coefficients based on cross-sectional results. It may also be the case, however, that false positives in the linked datasets bias coefficients downwards. Given the current preliminary status of the crosswalks, we see this exercise as a check of the robustness of our cross-sectional results rather than a preferable approach. In-progress research linking married couples across complete-count IPUMS datasets at the Minnesota Population Center (Helgertz et al. 2019)-which should result in a larger number of cases with very low levels of false positives-and continued research creating and evaluating panel datasets by other researchers will allow future studies to confirm, modify or reject the conclusions drawn here. 


\section{CONCLUSION}

Historians have long been puzzled by the U. S. fertility decline, which began before significant urbanization, industrialization, and mortality decline. Unfortunately, poor data have hampered research. Early research relied on state and county-level child woman ratios calculated from published census data, which are sensitive to changes in nuptiality and child mortality. In the last few decades, IPUMS microdata samples of the 1850-1880 censuses have opened up new analytical possibilities, including the estimation of age-specific marital fertility rates and marital fertility differentials. These new data suggest that a significant portion of the nineteenth-century decline in child woman ratios, especially in the first half of the century, was driven by declines in nuptiality and increases in child mortality. State and county differentials in child-woman ratios, moreover, also reflected significant differentials in the timing and incidence of marriage and child mortality. The data are also consistent, nonetheless, with a gradual shift from a demographic regime in which fertility was regulated by the timing and incidence of marriage to a demographic regime in which fertility was regulated by couples practicing marital fertility control (Hacker 2003; Haines et al. 2020). This transition was accelerated in the Northeast, which experienced low levels of marital fertility early in the century. Indirect estimation methods are able to detect paritydependent fertility control in New England and the Mid-Atlantic census divisions prior to the Civil War, suggesting that significant proportions of couples were able to curtail their childbearing after reaching a targeted number of surviving children (Hacker 2016).

We relied on new complete-count IPUMS datasets for the 1830-1880 censuses and countylevel data-including new data on farm values, manufacturing activity, transportation, religious denominations, and banking institutions - to examine alternative theories of the fertility decline. These data allowed us to model couples' recent net marital fertility, thereby avoiding the inherent ambiguity in county-level CWR models as to whether the mechanism linking fertility and independent variables was via adjustments to the timing and incidence of marriage or via couples' practice of marital fertility control. 
The land availability, local labor market/child default, conventional structuralist, ideational, child demand/quality-quantity tradeoff, and life-cycle savings hypotheses all receive some support from the data. Variables associated with classic demographic transition theory and ideational theories had the greatest substantive impact on marital fertility. Despite the strong influence of nuptiality on fertility early in the century, we found evidence of marital fertility control consistent with hypotheses as early as 1830 , with urban couples having significantly fewer children, all else being equal, than rural couples. The addition of occupation data beginning with the 1840 census allowed us to examine occupational differences in fertility, which were again consistent with hypotheses. Farm couples, for example, had more children under the age of five than non-farm couples, consistent with expectations that couples adjusted their childbearing in response to differentials in the perceived costs and benefits of children by husbands' occupations. We stressed, however, that lower childbearing rates among wealthier couples in years with individuallevel wealth data (1850-1870) is inconsistent with the land availability hypothesis, which assumes couples adjusted their fertility in response to their ability to purchase nearby farms for their children. Banks proved to be a significant correlate of marital fertility in all census years, providing consistent support for the life-cycle savings hypothesis. Although the cross-sectional models used in this study do not allow us to make causal estimates, we conclude that the evidence is consistent with the hypothesis that banks facilitated financial savings, lowering couples' incentives for having a large number of children as an alternative way to save for old age. A test of these results with preliminary panel datasets of couples linked between the 1850-1860 and 1860-1870 censuses largely confirm the results from the cross-sectional analysis. 


\section{REFERENCES}

Abramitzky, Ran, Leah Boustan, and Myera Rashid. 2020. “Census Linking Project: Version 1.0” [dataset]. https://censuslinkingproject.org. Accessed June 25, 2020.

Atack, Jeremy, Matthew Jaremski, and Peter Rousseau. 2015. "American Banking and the Transportation Revolution before the Civil War." Journal of Economic History. Vol. 74. pp. 943-986.

Basso, Alberto, and David Cuberes. 2013. "Fertility and Financial Development: Evidence from U.S. Counties in the $19^{\text {th }}$ Century." Sheffield Economic Research Paper Series. SERP Number 2013011. (September). University of Sheffield, UK.

Bateman, Fred and James D. Foust. 1974. "A Sample of Rural Households Selected from the 1860 Manuscript Censuses." Agricultural History. Vol. 48, No. 1 (January). pp. 75-93.

Becker, G. S. 1981. A Treatise on the Family. Harvard University Press. Cambridge, MA.

Bailey, Martha, Connor Cole, Morgan Henderson, and Catherine Massey. 2019. "How well do automated methods perform in historical samples? Evidence from new ground truth." NBER Working Paper No. 24019.

Becker, S. O., F. Cinnirella and L. Woessmann. 2010. "The trade-off between fertility and education: Evidence from before the demographic transition." Journal of Economic Growth 15:177-204.

Brodie, Janet Farrell. 1994. Contraception and abortion in 19th-century America. Ithaca, NY: Cornell University Press.

Bodenhorn, Howard. 2003. State Banking in Early America: A New Economic History. New York: Oxford University Press.

Carter, Susan B, Roger L. Ransom, and Richard Sutch. 2004. "Family Matters: The Life-Cycle Transition and the Antebellum Fertility Decline." In Timothy W; Guinnane, William A. Sundstrom, and Warren C. Whatley, eds. History Matters: Essays on Economic Growth, Technology, and Demographic Change. Stanford, CA: Stanford University Press. pp. 271327.

Carter, Susan B., Scott Sigmund Gartner, Michael R. Haines, Alan L. Olmstead, Richard Sutch, and Gavin Wright, eds. 2006. Historical Statistics of the United States: Earliest Times to the Present. Millennial Edition. NY: Cambridge University Press. 5 volumes.

Coale, Ansley J., and Melvin Zelnik. 1963. New Estimates of Fertility and Population in the United States: A Study of Annual White Births from 1855 to 1960 and of Completeness of Enumeration in the Censuses from 1880 to 1960. Princeton, NJ: Princeton University Press. Craig, Lee A. 1993. To Sow One Acre More: Childbearing and Farm Productivity in the Antebellum North. Baltimore, MD: Johns Hopkins University Press. 
Dribe, Martin, J. David Hacker, and Francesco Scalone. 2014. "Socioeconomic Status and Net Fertility during the Fertility Decline: A Comparative Analysis of Canada, Iceland, Sweden, Norway and the USA." Population Studies. Vol. 68, no. 2. pp. 135-149.

Dribe, M., Oris, M., and Pozzi, L. 2014. "Socioeconomic status and fertility before, during, and after the demographic transition: An introduction." Demographic Research. Vol. 31, No. 7. pp. 161-182.

Easterlin, Richard A. 1976. "Population Change and Farm Settlement in the Northern United States." Journal of Economic History. Vol. 36, No. 1 (March). pp. 45-75.

Easterlin, Richard A., George Alter, and Gretchen Condran. 1978. "Farms and Farm Families in Old and New Areas: The Northern States in 1860." In Tamara K. Hareven and Maris A. Vinovskis, eds. Family and Population in Nineteenth-Century America. Princeton, NJ: Princeton University Press. pp. 22-84.

Easterlin, R. A. and E. C. Crimmins. 1985. The Fertility Revolution. A Supply-Demand Analysis. Chicago: The University of Chicago Press.

Feigenbaum, James J. 2016. “A Machine Learning Approach to Census Record Linking.: http://scholar.harvard.edu/files/ifeigenbaum/files/feigenbaumcensuslink.pdf?m=1423080976. Accessed June 25, 2020.

Ferrie, Joseph P. 1996. "A New Sample of Males Linked from the 1850 Public Use Micro Sample of the Federal Census of Population to the 1860 Federal Census Manuscript Schedules." Historical Methods 29 (4):141-156.

Finkel, S. 1995. Causal analysis with panel data. Thousand Oaks: Sage.

Forster, Colin, G.S.L. Tucker, and Helen Bridge. 1972. Economic Opportunity and Whiter American Fertility Ratios, 1800-1860. New Haven: Yale University Press.

Goeken, Ron, Lap Huynh, Thomas Lenius, and Rebecca Vick. 2011. "New Methods of Census Record Linking." Historical Methods. 44:7-14

Guest, Avery M. 1981. "Social structure and U.S. inter-state fertility differentials in 1900." Demography 18: 465-487.

Guest, Avery M., and Stewart E. Tolnay. 1983. "Children's roles and fertility: Late nineteenthcentury United States." Social Science History 7.4: 355-380.

Guinnane, Timothy W. 2011. The historical fertility transition: A guide for economists. Journal of Economic Literature. No. 49. pp. 589-614.

Hacker, J. David. 1999. "Child Naming, Religion, and the Decline of Marital Fertility in NineteenthCentury America." History of the Family: An International Quarterly. Vol. 4, No. 3. pp. 339365.

. 2003. "Rethinking the 'Early' Decline of Fertility in the United States." Demography. Vol. 4, No. 4 (November). pp. 605-620. 
. 2008. "Economic, Demographic, and Anthropometric Correlates of First Marriage in the Mid Nineteenth-Century United States." Social Science History. Vol. 32, No. 3 (Fall). pp. 307-345.

. 2010. "Decennial life tables for the white population of the United States, 1790-1900." Historical Methods. 43, 45-79.

. 2011. "A Census-Based Count of the Civil War Dead." Civil War History. Vol. 57, No. 4. pp. 307-348.

. "Ready, Willing and Able? Impediments to Onset of Marital Fertility Decline in the United States." Demography. Vol. 53, No. 6 (December). pp. 1657-1692.

. "Reconstruction of birth histories using children ever born and children surviving data from the 1900 and 1910 United States Censuses." Historical Methods. 53(1): 28-52.

Hacker, J. David and Evan Roberts. 2017. "The Impact of Kin Availability, Parental Religiosity, and Nativity on Fertility Differentials in the Late Nineteenth-Century United States," Demographic Research. Vol. 37(34), pp. 1049-1080.

. 2019. "Fertility decline in the United States, 1850-1940: New Evidence from CompleteCount Datasets." Annales de Démographie Historique. Vol. 138, No. 2, pp. 143-147.

Haines, Michael. R. 1977. Fertility, Nuptiality, and Occupation: A Study of Coal Mining Populations and Regions in England and Wales in the Mid-Nineteenth Century. The Journal of Interdisciplinary History. Vol. 8, No. 2 (Autumn). pp. 245-280. . 1989. "American Fertility in Transition: New Estimates of Birth Rates in the United States, 1900-1910." Demography. Vol. 26, No. 1 (February). pp. 137-148. . 1996. "Long Term Marriage Patterns in the United States from Colonial Times to the Present." The History of the Family: An International Quarterly. Vol. 1 pp. 15-39. . 2000. "The Population of the United States, 1790-1920." In Stanley Engerman and Robert Gallman, eds. The Cambridge Economic History of the United States. Vol. 2. "The Long Nineteenth Century." NY: Cambridge University Press. pp. 143-205.

Haines, Michael R., and J. David Hacker. 2011. "Spatial Aspects of the American Fertility Transition in the Nineteenth Century." In Myron P. Gutmann, Glenn D. Deane, Emily R. Merchant, and Kenneth M. Sylvester, eds. Navigating Space and Time in Historical Population Studies. (NY: Oxford University Press, 2011). pp. 37-63.

Haines, Michael R., and Richard H. Steckel, eds. 2000. A population history of North America. Cambridge University Press.

Hammond, Bray. 1957. Banks and Politics in America: From the Revolution to the Civil War. Princeton: Princeton University Press.

Helgertz, Jonas, Jacob Wellington, K. Thompson, and Joseph P. Price. "A new strategy for linking census data: A case study linking the 1900 and 1910 full-count U.S. censuses." Paper 
presented at the annual meeting of the Social Science History Association, Chicago, Illinois, November 22.

ICPSR. 2010. Inter-University Consortium for Political and Social Research. Study Number 2896.

"Historical Demographic, Economic, and Social Data: The United States, 1790-2002."

(Michael R. Haines and ICPSR). (Ann Arbor: ICPSR, University of Michigan).

ICPSR. 2014. Inter-University Consortium for Political and Social Research. Study Number 35206.

"United States Agricultural Data, 1840-2012." (Michael R. Haines, Price Fishback, and Paul Rhode). (Ann Arbor: ICPSR, University of Michigan).

Jaremski, Matthew. 2014. “National Banking's Role in U.S. Industrialization, 1850-1900” Journal of Economic History Vol. 74, pp. 109-140.

Jaremski, Matthew and Peter Rousseau. 2013. "Banks, Free Banks, and Economic Growth."

Economic Inquiry Vol. 51, pp. 1603-1621.

Jones, Larry E., and Michele Tertilt. (2008). An economic history of fertility in the United States:

1826-1960. In P. Rupert (ed.), Frontiers in family economics (Vol.1, pp. 165-230). Bingley, UK: Emerald Group Publishing.

Knodel, John. 1974. The Decline of Fertility in Germany, 1871-1939. Princeton: Princeton University Press.

Knodel, John, and Etienne van de Walle. 1979. "Lessons from the Past: Policy Implications of Historical Fertility Studies." Population and Development Review. Vol. 5, No. 2. pp. 217245.

Leet, Donald R. 1976. "The Determinants of Fertility Transition in Antebellum Ohio." Journal of Economic History. Vol. 36, No. 2 (June). pp. 359-378.

Lesthaeghe, Ron. 1980. "On the Social Control of Human Reproduction." Population and Development Review. Vol. 6, No. 4 (March). pp. 527-548. . 1983. "A Century of Demographic and Cultural Change in Western Europe: An Exploration of Underlying Dimensions." Population and Development Review. Vol. 9, No. 3. pp. 411-435.

Maloney, Thomas, Heidi Hanson, and Ken Smith. 2014. "Occupation and fertility on the frontier: Evidence from the State of Utah. Demographic Research. Vol. 30(29), pp. 853-886.

McCusker, John J., and Russell R. Menard. 1985. The Economy of British America, 1607-1789. Chapel Hill, NC: University of North Carolina Press.

Modigliani, Franco. 1966. "The Life Cycle Hypothesis of Saving, the Demand for Wealth and the Supply of Capital." Social Research. Vol. 33, No. 2. Pp. 160-217.

Notestein, Frank W. 1953. "The Economics of Population and Food Supplies. I. The Economic Problems of Population Change." Proceedings of the Eighth International Conference of Agricultural Economists. London, England: Oxford University Press. 
Preston, Samuel H., and Michael R. Haines. 1991. Fatal Years: Child Mortality in Late Nineteenth Century America. Princeton, NJ: Princeton University Press.

Ruggles, Steven, Catherine Fitch, and Evan Roberts. 2018. "Historical Census Record Linkage." Annual Review of Sociology. Vol. 44, No. 1, pp. 19-37.

Ruggles, Steven, Sarah Flood, Ronald Goeken, Josiah Grover, Erin Meyer, Jose Pacas and Matthew Sobek. 2020. IPUMS USA: Version 10.0 [dataset]. Minneapolis, MN: IPUMS, 2020. https://doi.org/10.18128/D010.V10.0

Ruggles, Steven and Diana Magnuson. 2020. Census technology, politics, and institutional change, 1790-2020." Journal of American History 107: 19-51

Scalone, Francesco and Marin Dribe. 2017. "Testing child-woman ratios and the own-children method on the 1900 Sweden census: Examples of indirect fertility estimates by socioeconomic status in a historical population." Historical Methods. 50(1): 16-29.

Smith, Daniel Scott. 1987. "'Early Fertility Decline in America: A Problem in Family History.” Journal of Family History. Vol. 12, Nos. 1-3. pp. 73-84.

. 1993. "American family and demographic patterns and the Northwest European model." Continuity and Change 8: 389-415.

Steckel, Richard H. 1992. "The Fertility Transition in the United States: Tests of Alternative Hypotheses. In Claudia Goldin and Hugh Rockoff (eds.), Strategic Factors in Nineteenth Century American Economic History: A Volume to Honor Robert W. Fogel. Chicago: University of Chicago Press. pp. $351-374$.

Sundstrom, William A., and Paul A. David. 1988. "Old-Age Security Motives, Labor Markets, and Farm Family Fertility in Antebellum America." Explorations in Economic History. Vol. 25, No. 2 (April). pp. 164-197.

Tolnay, Stewart E. 1981. "Trends in Total and Marital Fertility for Black Americans, 1886-1899." Demography. Vol. 18, No. 4. pp. 443-463.

Tucker, George (Joseph Atterly, pseudo.). 1827. A Voyage to the Moon. (New York: Elam Bliss). Tucker, George. 1855. Progress of the United States in Population \& Wealth in Fifty Years as Exhibited by the Decennial Census from 1790 to 1840. NY: Press of Hunt's Merchant Magazine.

Wahl, Jenny Bourne. 1992. "Trading quantity for quality: Explaining the decline in American fertility in the nineteenth century." In Claudia Goldin \& Hugh Rockoff (eds.), Strategic Factors in Nineteenth Century American Economic History: A Volume to Honor Robert W. Fogel (pp. 375-397). Chicago, IL: University of Chicago Press.

Wanamaker, Marianne H. 2012. "Industrialization and fertility in the nineteenth century: Evidence from South Carolina." The Journal of Economic History 72.1: 168-196. 
Weber, Warren. 2005. Listing of all State Banks with Beginning and Ending Dates. Research Department, Federal Reserve Bank of Minneapolis http://research.mpls.frb.fed.us/research/economists/wewproj.html . 2008. Balance sheets for U.S. Antebellum State Banks. Research Department, Federal Reserve Bank of Minneapolis. http://research.mpls.frb.fed.us/research/economists/wewproj.html

Winegarden, C. R., and Mark Wheeler. 1992. The role of economic growth in the fertility transition in Western Europe: Econometric evidence. Economica, 59, 421-435.

Woods, Robert. 2000. The Demography of Victorian England and Wales. Cambridge, UK: Cambridge University Press.

Yasuba, Yasukichi. 1962. Birth Rates of the White Population of the United States, 1800-1860: An Economic Analysis. Baltimore: The Johns Hopkins University Press. 
Figure 1. White woman-child ratios in the United States, 1800-1880

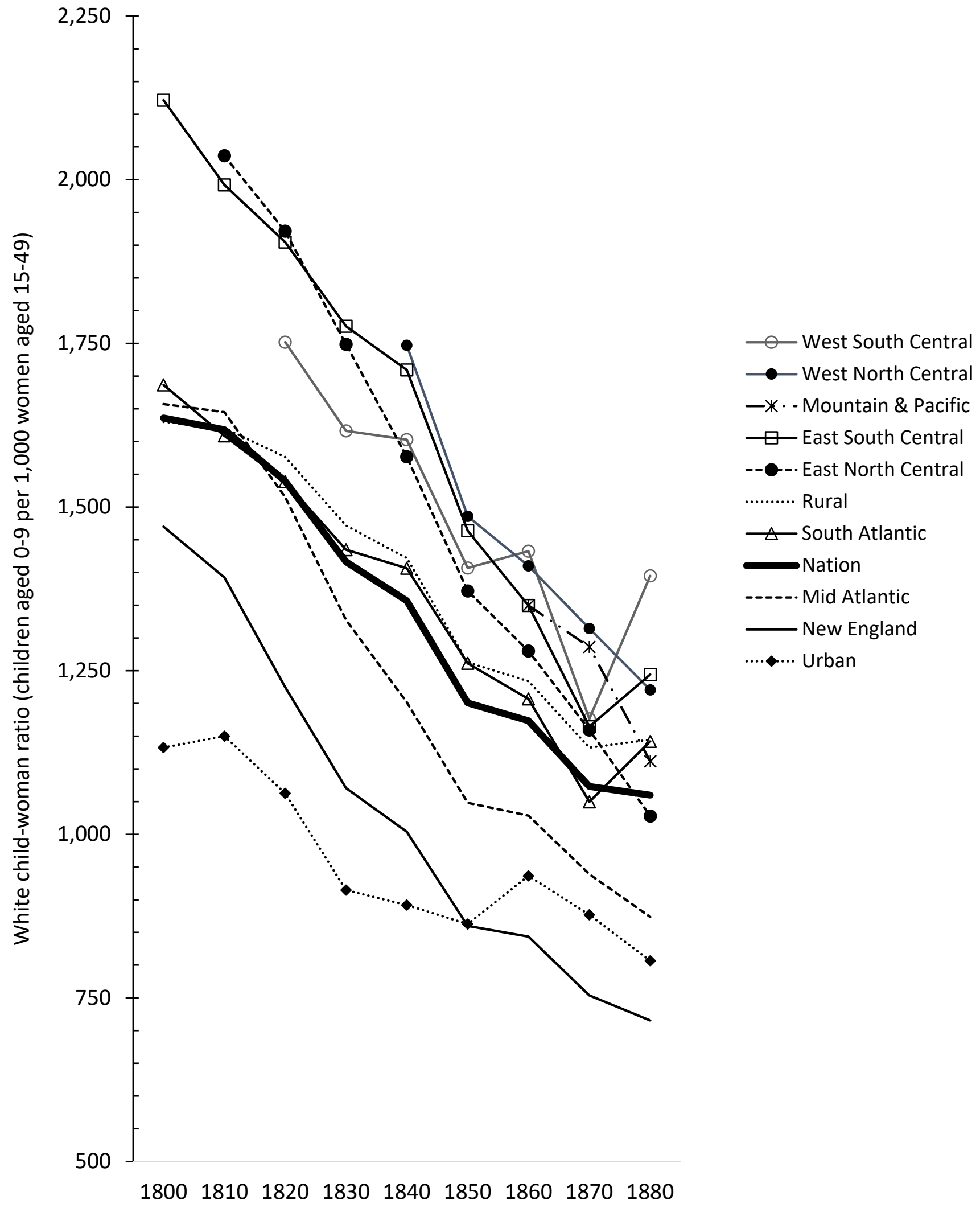

Census year 
Table 1. OLS regressions of children less than age five in the household, 1830-1850, parsimonous models

\begin{tabular}{|c|c|c|c|c|}
\hline & \multicolumn{4}{|c|}{ Census year } \\
\hline & 1830 & 1840 & 1850 & \\
\hline \multicolumn{5}{|l|}{ Age group of imputed wife } \\
\hline $15-19$ & $-66.1 * * *$ & $-67.6 * * *$ & -67.8 & $* * *$ \\
\hline $20-29$ & ref. & ref. & ref. & \\
\hline $30-39$ & $11.7 * * *$ & $10.5 * * *$ & 2.4 & $* * *$ \\
\hline $40-49$ & $-44.9 * * *$ & $-47.5 * * *$ & -52.6 & $* * *$ \\
\hline \multicolumn{5}{|l|}{ Residence type } \\
\hline Rural & ref. & ref. & ref. & \\
\hline Urban, population less than 10,000 & $-12.8 * * *$ & $-10.8 * * *$ & -13.2 & $* * *$ \\
\hline Urban, $10,000-24,999$ & $-17.8 * * *$ & $-13.8 * * *$ & -9.3 & $* * *$ \\
\hline Urban, 25,000 - 99,999 & $-16.7 * * *$ & $-13.6 * * *$ & -13.7 & $* * *$ \\
\hline Urban, 100,00 or more & $-16.6 * * *$ & $-11.9 * * *$ & -14.5 & $* * *$ \\
\hline \multicolumn{5}{|l|}{ Bank availability } \\
\hline No banks in county & ref. & ref. & ref. & \\
\hline 1 bank in county & $-4.4 * * *$ & $-5.3 * * *$ & -7.4 & $* * *$ \\
\hline 2 banks in county & $-6.8 * * *$ & $-6.7 * * *$ & -8.5 & $* * *$ \\
\hline 3 banks in county & $-4.4 * * *$ & $-8.8 * * *$ & -10.0 & $* * *$ \\
\hline 4 or more banks in county & $-7.2 * * *$ & $-8.7 * * *$ & -10.5 & $* * *$ \\
\hline Mean number of children age $0-4$ & 1.44 & 1.35 & 1.17 & \\
\hline Number of couples & 609,158 & 891,204 & $1,124,656$ & \\
\hline R-square & 0.095 & 0.088 & 0.073 & \\
\hline
\end{tabular}

Notes: All models employ state-level fixed effects. The analytical universe includes imputed nuclear households with one white couple present. See text for definition and selection criteria. The dependent variable is the total number of white children ages 0-4 in the household.

${ }^{*} p<0.05 ;{ }^{* *} p<0.01 ; * * * p<0.001$ 
Table 2. OLS regressions of children less than five in the household, 1830-1850, full models

\begin{tabular}{|c|c|c|c|}
\hline \multirow[b]{2}{*}{ Year } & \multicolumn{3}{|c|}{ Census year } \\
\hline & 1830 & 1840 & 1850 \\
\hline \multicolumn{4}{|l|}{ Age group of imputed wife } \\
\hline $15-19$ & $-66.1 * * *$ & $-67.6 * * *$ & $-66.5 * * *$ \\
\hline $20-29$ & ref. & ref. & ref. \\
\hline $30-39$ & $11.7 * * *$ & $10.2 * * *$ & $0.9 * * *$ \\
\hline $40-49$ & $-44.8 * * *$ & $-47.8 * * *$ & $-54.1 * * *$ \\
\hline \multicolumn{4}{|l|}{ Occupation group of males in household } \\
\hline Agricultural & & ref. & ref. \\
\hline Professional, engineering & & $-23.3 * * *$ & $-14.3 * * *$ \\
\hline Commercial & & $-16.8 * * *$ & $-10.2 * * *$ \\
\hline Manufacturing & & $-7.3 * * *$ & $-1.9 * * *$ \\
\hline Mining & & $-3.7 * * *$ & $8.1 * * *$ \\
\hline Navigational & & $-11.0 * * *$ & $-5.4 * * *$ \\
\hline No occupation & & $-7.8 * * *$ & $27.6 * * *$ \\
\hline Mixed occupations & & $-1.8 * * *$ & $-4.7 * * *$ \\
\hline \multicolumn{4}{|c|}{ Literacy of household members 20 \& over } \\
\hline One or more illiterate & & ref. & ref. \\
\hline Both literate & & $-7.6 * * *$ & $-2.7 * * *$ \\
\hline \multicolumn{4}{|l|}{ Nativity } \\
\hline Native-born couple & ref. & & ref. \\
\hline Foreign-born couple & -0.8 & & -0.2 \\
\hline \multicolumn{4}{|l|}{ Slave holdings } \\
\hline No slaves in household & ref. & ref. & \\
\hline Less than 20 slaves & $-4.6 * * *$ & $-1.9 * * *$ & \\
\hline 20 or more slaves & $-14.9 * * *$ & $-10.7 * * *$ & \\
\hline \multicolumn{4}{|l|}{ Real estate wealth } \\
\hline None & & & $-9.6 * * *$ \\
\hline Moderate (\$100 - \$2499) & & & ref. \\
\hline High (\$2500 or more) & & & $-6.5 * * *$ \\
\hline \multicolumn{4}{|l|}{ Residence type } \\
\hline Rural & ref. & ref. & ref. \\
\hline Urban, population less than 10,000 & $-12.7 * * *$ & $-6.5 * * *$ & $-10.5 * * *$ \\
\hline Urban, $10,000-24,999$ & $-17.7 * * *$ & $-9.2 * * *$ & $-7.3 * * *$ \\
\hline Urban, 25,000 - 99,999 & $-16.7 * * *$ & $-10.0 * * *$ & $-10.8 * * *$ \\
\hline Urban, 100,00 or more & $-16.5 * * *$ & $-8.2 * * *$ & $-11.7 * * *$ \\
\hline Transportation & & $-3.9 * * *$ & $-6.7 * * *$ \\
\hline School attendance, whites age 5-17 & & & $-19.2 * * *$ \\
\hline \multicolumn{4}{|l|}{ Bank availability } \\
\hline No banks in county & ref. & ref. & ref. \\
\hline 1 bank in county & $-4.3 * * *$ & $-3.7 * * *$ & $-5.7 * * *$ \\
\hline 2 banks in county & $-6.6 * * *$ & $-4.0 * * *$ & $-6.1 * * *$ \\
\hline 3 banks in county & $-4.3 * * *$ & $-5.7 * * *$ & $-8.2 * * *$ \\
\hline 4 or more banks in county & $-7.1 * * *$ & $-5.3 * * *$ & $-8.4 * * *$ \\
\hline
\end{tabular}


Notes: All models employ state-level fixed effects. See table 2 for universe selection criteria. Foreign-born couples include couples with one or both partners foreign born. Literate couples include only couples in which both partners could read and write. The dollar figure to define the cutoff between moderate and high wealth couples was chosen to classify approximately 10 percent of all couples as high wealth. In 1850, high real estate wealth couples reported $\$ 2500$ or more in real estate wealth. Transportation is a dummy variable indicating if the couple's county of residence was on a canal, river, or other navigable waterway in 1840 and if on a canal, river, or other navigable waterway or had a railroad in 1850 . Proportion attending school is the proportion of white children age 5-17 attending school in the county. The dependent variable is the total number of white children ages 0-4 in the household.

${ }^{*} p<0.05 ; * * p<0.01 ; * * * p<0.001$ 


\begin{tabular}{|c|c|c|c|c|c|c|c|c|}
\hline \multirow[b]{3}{*}{ Age group of imputed wife } & \multicolumn{8}{|c|}{ Census year } \\
\hline & \multicolumn{2}{|l|}{1850} & \multicolumn{2}{|l|}{1860} & \multicolumn{2}{|l|}{1870} & \multicolumn{2}{|l|}{1880} \\
\hline & & & & & & & & \\
\hline $15-19$ & -71.0 & $* * *$ & -72.3 & $* * *$ & -61.0 & $* * *$ & -61.4 & $* * *$ \\
\hline $20-24$ & ref. & & ref. & & ref. & & ref. & \\
\hline $25-29$ & 27.5 & $* * *$ & 22.3 & $* * *$ & 23.2 & $* * *$ & 22.5 & $* * *$ \\
\hline $30-34$ & 20.2 & $* * *$ & 12.4 & $* * *$ & 11.8 & $* * *$ & 7.9 & $* * *$ \\
\hline $35-39$ & 4.0 & $* * *$ & -7.5 & $* * *$ & -8.3 & $* * *$ & -15.7 & $* * *$ \\
\hline $40-44$ & -29.4 & $* * *$ & -41.7 & $* * *$ & -43.8 & $* * *$ & -53.4 & $* * *$ \\
\hline $45-49$ & -74.7 & $* * *$ & -84.5 & $* * *$ & -86.8 & $* * *$ & -96.0 & $* * *$ \\
\hline Age differential from spouse & -0.1 & $* * *$ & -0.2 & $* * *$ & -0.2 & $* * *$ & -0.6 & $* * *$ \\
\hline \multicolumn{9}{|l|}{ Occupation group of spouse (1950 classification) } \\
\hline Professional & -17.5 & $* * *$ & -18.4 & $* * *$ & -22.3 & $* * *$ & -23.2 & $* * *$ \\
\hline Farmer & ref. & & ref. & & ref. & & ref. & \\
\hline Manager-Official-Proprietor & -14.9 & $* * *$ & -16.1 & $* * *$ & -20.1 & $* * *$ & -22.6 & $* * *$ \\
\hline Clerial \& Sales & -20.1 & $* * *$ & -19.6 & $* * *$ & -24.0 & $* * *$ & -25.6 & $* * *$ \\
\hline Craftsmen & -8.9 & $* * *$ & -8.6 & $* * *$ & -12.6 & $* * *$ & -12.6 & $* * *$ \\
\hline Operatives \& Apprentices & -9.7 & $* * *$ & -9.9 & $* * *$ & -12.2 & $* * *$ & -11.5 & $* * *$ \\
\hline Service Worker & -15.1 & $* * *$ & -16.3 & $* * *$ & -20.1 & $* * *$ & -19.7 & $* * *$ \\
\hline Farm Laborer & -49.8 & $* * *$ & -8.3 & $* * *$ & -9.8 & $* * *$ & -12.3 & $* * *$ \\
\hline Laborers & -7.0 & $* * *$ & -7.1 & $* * *$ & -10.4 & $* * *$ & -6.5 & $* * *$ \\
\hline Miners & -2.2 & $* *$ & -3.8 & $* * *$ & -2.2 & $* * *$ & 3.1 & $* *$ \\
\hline Non-Occupational Response & -31.6 & $* * *$ & -13.3 & $* * *$ & -22.3 & $* * *$ & -26.7 & $* * *$ \\
\hline \multicolumn{9}{|l|}{ Literacy of couple } \\
\hline One or both spouses cannot read or write & ref. & & ref. & & ref. & & ref. & \\
\hline Both spouses can read and write & -11.3 & $* * *$ & -11.7 & $* * *$ & -9.3 & $* * *$ & -10.2 & $* * *$ \\
\hline \multicolumn{9}{|l|}{ Nativity of couple } \\
\hline \multicolumn{9}{|l|}{ Both spouses native born } \\
\hline One or both spouses born Germany & 0.4 & & 21.3 & $* * *$ & 30.1 & $* * *$ & 34.7 & $* * *$ \\
\hline One or both spouses born Ireland & 2.5 & $* * *$ & 22.2 & $* * *$ & 29.2 & $* * *$ & 28.7 & $* * *$ \\
\hline One or both spouses born Great Britain & 1.5 & $* * *$ & 8.3 & $* * *$ & 9.7 & $* * *$ & 13.1 & $* * *$ \\
\hline One or both spouses born Canada & 13.1 & $* * *$ & 15.5 & $* * *$ & 17.4 & $* * *$ & 18.1 & $* * *$ \\
\hline One or both spouses other foreign born & -4.0 & $* * *$ & 15.5 & $* * *$ & 18.4 & $* * *$ & 26.1 & $* * *$ \\
\hline \multicolumn{9}{|l|}{ Residence type } \\
\hline Rural & ref. & & ref. & & ref. & & ref. & \\
\hline Urban, population less than 10,000 & -8.2 & $* * *$ & -8.9 & $* * *$ & -8.5 & $* * *$ & -8.0 & $* * *$ \\
\hline Urban, $10,000-24,999$ & -6.5 & $* * *$ & -9.0 & $* * *$ & -8.2 & $* * *$ & -7.1 & $* * *$ \\
\hline Urban, 25,000 - 99,999 & -8.2 & $* * *$ & -7.8 & $* * *$ & -7.6 & $* * *$ & -7.0 & $* * *$ \\
\hline Urban, 100,00 or more & -6.4 & $* * *$ & -12.7 & $* * *$ & -7.5 & $* * *$ & -5.8 & $* * *$ \\
\hline \multicolumn{9}{|l|}{ Additional county-level control variables } \\
\hline School attendance, whites age 5-17 & -17.9 & $* * *$ & -9.8 & $* * *$ & -7.7 & $* * *$ & -11.3 & $* * *$ \\
\hline Proportion of labor force in manufacturing & -17.5 & $* * *$ & -10.4 & $* * *$ & -41.2 & $* * *$ & -23.9 & $* * *$ \\
\hline Average farm value per acre (In) & -1.2 & $* * *$ & -0.2 & $* *$ & -0.7 & $* * *$ & -1.3 & $* * *$ \\
\hline Proportion of farm acres improved & -9.0 & $* * *$ & -10.4 & $* * *$ & -10.1 & $* * *$ & -8.8 & $* * *$ \\
\hline \multicolumn{9}{|l|}{ Bank availability } \\
\hline No banks in county & ref. & & ref. & & ref. & & ref. & \\
\hline 1 bank in county & -4.4 & $* * *$ & -3.1 & $* * *$ & -2.4 & $* * *$ & -3.1 & $* * *$ \\
\hline 2 banks in county & -5.3 & $* * *$ & -5.0 & $* * *$ & -3.9 & $* * *$ & -3.9 & $* * *$ \\
\hline 3 banks in county & -6.6 & $* * *$ & -4.9 & $* * *$ & -5.4 & $* * *$ & -6.1 & $* * *$ \\
\hline 4 or more banks in county & -5.8 & $* * *$ & -6.2 & $* * *$ & -5.6 & $* * *$ & -6.2 & $* * *$ \\
\hline Mean number of children age $0-4$ & 0.994 & & 0.991 & & 0.907 & & 0.875 & \\
\hline
\end{tabular}


Notes: All models employ state-level fixed effects. The analytical universe includes all currently-married white women age 15-49 with spouses present in the household. See Table 2 for definition of school attendance variable. Proportion manufacturing is the proportion of the white population age 15-69 employed in manufacturing. Average farm value per acre is the natural log of the value in hundreds of dollars and includes improved and unimproved acreage. See www.ipums.org for dicussion of occupation (OCC1950) and size of place (SIZEPL). The dependent variable is the number of own ages 0-4 in the household as identified by the IPUMS variable NCHLT5.

${ }^{*} \mathrm{p}<0.05 ; * * p<0.01 ; * * * p<0.001$ 


\begin{tabular}{|c|c|c|c|c|c|c|c|c|}
\hline \multirow[b]{3}{*}{ Age group of imputed wife } & \multicolumn{8}{|c|}{ Census year } \\
\hline & \multicolumn{2}{|l|}{1850} & \multirow[t]{2}{*}{1860} & & \multicolumn{2}{|l|}{1870} & \multicolumn{2}{|l|}{1880} \\
\hline & & & & & & & & \\
\hline $15-19$ & -70.3 & $* * *$ & -70.5 & $* * *$ & -59.4 & $* * *$ & -61.3 & $* * *$ \\
\hline $20-24$ & \multicolumn{2}{|c|}{ ref. } & \multicolumn{2}{|c|}{ ref. } & \multicolumn{2}{|c|}{ ref. } & \multicolumn{2}{|c|}{ ref. } \\
\hline $25-29$ & 27.1 & $* * *$ & 21.7 & $* * *$ & 22.4 & $* * *$ & 22.4 & $* * *$ \\
\hline $30-34$ & 19.5 & $* * *$ & 11.4 & $* * *$ & 10.6 & $* * *$ & 7.8 & $* * *$ \\
\hline $35-39$ & 3.2 & $* * *$ & -8.6 & $* * *$ & -9.6 & $* * *$ & -15.7 & $* * *$ \\
\hline $40-44$ & -30.2 & $* * *$ & -42.8 & $* * *$ & -45.3 & $* * *$ & -53.4 & $* * *$ \\
\hline $45-49$ & -75.6 & $* * *$ & -85.7 & $* * *$ & -88.4 & $* * *$ & -96.0 & $* * *$ \\
\hline Age differential from spouse & -0.1 & $* * *$ & -0.2 & $* * *$ & -0.2 & $* * *$ & -0.6 & $* * *$ \\
\hline Labor force participation of mother & & & -9.7 & $* * *$ & -35.2 & $* * *$ & -37.8 & $* * *$ \\
\hline \multicolumn{9}{|l|}{ Occupation group of spouse (1950 classification) } \\
\hline Professional & -16.4 & $* * *$ & -17.1 & $* * *$ & -20.4 & $* * *$ & -22.5 & $* * *$ \\
\hline Farmer & \multicolumn{2}{|c|}{ ref. } & \multicolumn{2}{|c|}{ ref. } & \multicolumn{2}{|c|}{ ref. } & \multicolumn{2}{|c|}{ ref. } \\
\hline Manager-Official-Proprietor & -13.9 & $* * *$ & -15.4 & $* * *$ & -18.0 & $* * *$ & -22.2 & $* * *$ \\
\hline Clerial \& Sales & -18.6 & $* * *$ & -18.1 & $* * *$ & -21.8 & $* * *$ & -25.0 & $* * *$ \\
\hline Craftsmen & -8.1 & $* * *$ & -7.5 & $* * *$ & -11.0 & $* * *$ & -12.0 & $* * *$ \\
\hline Operatives \& Apprentices & -8.7 & $* * *$ & -8.4 & $* * *$ & -9.7 & $* * *$ & -10.6 & $* * *$ \\
\hline Service Worker & -13.8 & $* * *$ & -14.3 & $* * *$ & -16.6 & $* * *$ & -18.3 & $* * *$ \\
\hline Farm Laborer & -46.6 & $* * *$ & -4.6 & $* * *$ & -5.2 & $* * *$ & -11.4 & $* * *$ \\
\hline Laborers & -4.6 & $* * *$ & -3.8 & $* * *$ & -6.8 & $* * *$ & -5.9 & $* * *$ \\
\hline Miners & 0.0 & & -1.6 & $* *$ & 1.4 & $* * *$ & 3.2 & $* *$ \\
\hline Non-Occupational Response & -29.9 & $* * *$ & -9.9 & $* * *$ & -17.2 & $* * *$ & -25.7 & $* * *$ \\
\hline \multicolumn{9}{|l|}{ Literacy of couple } \\
\hline One or both spouses cannot read or write & \multicolumn{2}{|l|}{ ref. } & \multicolumn{2}{|l|}{ ref. } & ref. & & ref. & \\
\hline Both spouses can read and write & -11.2 & $* * *$ & -11.3 & $* * *$ & -9.6 & $* * *$ & -10.3 & $* * *$ \\
\hline Nativity of couple & & & & & & & & \\
\hline Both spouses native born & ref. & & ref. & & ref. & & ref. & \\
\hline One or both spouses born Germany & 0.4 & & 21.3 & $* * *$ & 29.5 & $* * *$ & 34.6 & $* * *$ \\
\hline One or both spouses born Ireland & 2.8 & $* * *$ & 23.4 & $* * *$ & 29.6 & $* * *$ & 28.7 & $* * *$ \\
\hline One or both spouses born Great Britain & 1.9 & $* * *$ & 8.9 & $* * *$ & 10.2 & $* * *$ & 13.5 & $* * *$ \\
\hline One or both spouses born Canada & 13.9 & $* * *$ & 16.3 & $* * *$ & 18.1 & $* * *$ & 18.4 & $* * *$ \\
\hline One or both spouses other foreign born & -3.2 & $* * *$ & 16.0 & $* * *$ & 19.2 & $* * *$ & 26.2 & $* * *$ \\
\hline Couples' combined real estate wealth & & & & & & & & \\
\hline None & -7.1 & $* * *$ & -3.8 & $* * *$ & -4.5 & $* * *$ & & \\
\hline Moderate & ref. & & ref. & & ref. & & & \\
\hline High & -5.4 & $* * *$ & -3.1 & $* * *$ & -4.1 & $* * *$ & & \\
\hline Couples' combined personal estate wealth & & & & & & & & \\
\hline None & & & -10.5 & $* * *$ & -7.0 & $* * *$ & & \\
\hline Moderate & & & ref. & & ref. & & & \\
\hline High & & & -2.4 & $* * *$ & -5.0 & $* * *$ & & \\
\hline Residence type & & & & & & & & \\
\hline Rural & ref. & & ref. & & ref. & & ref. & \\
\hline Urban, population less than 10,000 & -7.6 & $* * *$ & -7.8 & $* * *$ & -7.9 & $* * *$ & -7.9 & $* * *$ \\
\hline Urban, $10,000-24,999$ & -5.7 & $* * *$ & -8.4 & $* * *$ & -6.6 & $* * *$ & -7.0 & $* * *$ \\
\hline Urban, 25,000 - 99,999 & -7.8 & $* * *$ & -6.4 & $* * *$ & -6.5 & $* * *$ & -6.7 & $* * *$ \\
\hline Urban, 100,00 or more & -7.5 & $* * *$ & -12.7 & $* * *$ & -6.4 & $* * *$ & -5.8 & $* * *$ \\
\hline Additional county-level control variables & & & & & & & & \\
\hline Transportation & -5.1 & $* * *$ & -5.4 & $* * *$ & & & & \\
\hline School attendance, whites age 5-17 & -16.9 & $* * *$ & -10.6 & $* * *$ & -10.5 & $* * *$ & -11.2 & $* * *$ \\
\hline Proportion of labor force in manufacturing & -10.8 & $* * *$ & -4.6 & $* * *$ & -35.1 & $* * *$ & -20.2 & $* * *$ \\
\hline
\end{tabular}




\begin{tabular}{|c|c|c|c|c|c|c|c|c|}
\hline Average farm value per acre (In) & -0.4 & $* * *$ & 0.4 & $* * *$ & -0.2 & $* * *$ & -1.3 & $* * *$ \\
\hline Proportion of farm acres improved & -8.8 & $* * *$ & -6.8 & $* * *$ & -9.0 & $* * *$ & -8.7 & $* * *$ \\
\hline Proportion liberal/pietistic churches & -8.4 & $* * *$ & -12.2 & $* * *$ & -4.4 & $* * *$ & & \\
\hline \multicolumn{9}{|l|}{ Bank availability } \\
\hline No banks in county & ref. & & ref. & & ref. & & ref. & \\
\hline 1 bank in county & -3.5 & $* * *$ & -2.2 & $* * *$ & -2.1 & $* * *$ & -3.1 & $* * *$ \\
\hline 2 banks in county & -4.4 & $* * *$ & -4.2 & $* * *$ & -3.6 & $* * *$ & -3.9 & $* * *$ \\
\hline 3 banks in county & -5.5 & $* * *$ & -3.9 & $* * *$ & -5.2 & $* * *$ & -6.2 & $* * *$ \\
\hline 4 or more banks in county & -5.1 & $* * *$ & -5.2 & $* * *$ & -5.3 & $* * *$ & -6.3 & $* * *$ \\
\hline Mean number of children age $0-4$ & 0.993 & & 0.991 & & 0.906 & & 0.875 & \\
\hline Number of couples & $2,554,825$ & & $3,647,177$ & & $4,551,750$ & & 630,420 & \\
\hline R-square & 0.136 & & 0.148 & & 0.145 & & 0.153 & \\
\hline
\end{tabular}

Notes: All models employ state-level fixed effects. . See www.ipums.org for dicussion of occupation (OCC1950) and size of place (SIZEPL). The dollar figure to define the cutoff between moderate and high wealth couples was chosen to classify approximately 10 percent of all couples as high wealth. In 1850, high real estate wealth couples reported $\$ 2500$ or more in real estate wealth. In 1860, couples with high real estate wealth reported $\$ 3500$ or more in real estate wealth, while couples with high personal estate wealth reported $\$ 2000$ or more in personal estate. In 1870 , couples with high real estate wealth reported $\$ 5000$ or more in real estate, while couples with high personal estate wealth reported $\$ 2000$ or more in personal estate. Proportion "liberal/individualistic" churches is the proportion of all church accomodations Congregationalist, Presbyterian, Unitarian and Universalist. See Tables 2 and 3 for definitions of other county-level variables. The dependent variable is the number of own ages 0-4 in the household as identified by the IPUMS variable NCHLT5.

${ }^{*} p<0.05 ;{ }^{* *} p<0.01 ; * * * p<0.001$ 


\begin{tabular}{|c|c|c|c|c|}
\hline \multirow{2}{*}{ Occupation group of spouse (1950 classificatior } & \multicolumn{2}{|c|}{ 1850-1860 panel } & \multicolumn{2}{|c|}{ 1860-1870 panel } \\
\hline & & & & \\
\hline Professional & $-9.1 * * *$ & $-6.8 * * *$ & $-11.4 * * *$ & $-9.0 * * *$ \\
\hline Farmer & ref. & ref. & ref. & ref. \\
\hline Manager-Official-Proprietor & $-10.6 * * *$ & $-8.7 * * *$ & $-10.2 * * *$ & $-8.0 * * *$ \\
\hline Clerial \& Sales & $-9.4 * * *$ & $-7.4 * * *$ & $-12.9 * * *$ & $-10.6 * * *$ \\
\hline Craftsmen & $-5.4 * * *$ & $-4.3 * * *$ & $-6.7 * * *$ & $-5.8 * * *$ \\
\hline Operatives \& Apprentices & $-5.8 * * *$ & $-4.7 * * *$ & $-7.5 * * *$ & $-6.5 * * *$ \\
\hline Service Worker & $-10.9 * * *$ & $-9.1 * * *$ & $-6.8 * * *$ & $-5.1 * * *$ \\
\hline Farm Laborer & -1.4 & 3.1 & 0.9 & 1.2 \\
\hline Laborers & $1.2 *$ & $1.4 * *$ & $1.3 *$ & $1.5 * *$ \\
\hline Miners & $5.0 *$ & $5.3 *$ & $5.3 * *$ & $5.4 * *$ \\
\hline Non-Occupational Response & $-8.1 * * *$ & $-5.9 * * *$ & $-2.3 * * *$ & $-1.3 * *$ \\
\hline \multicolumn{5}{|l|}{ Literacy of couple } \\
\hline One or both spouses cannot read or write & ref. & ref. & ref. & ref. \\
\hline Both spouses can read and write & $-4.2 * * *$ & $-2.2 * * *$ & $-6.3 * * *$ & $-4.2 * * *$ \\
\hline \multicolumn{5}{|l|}{ Nativity of couple } \\
\hline \multicolumn{5}{|l|}{ Both spouses native born } \\
\hline One or both spouses born Germany & $18.6 * * *$ & $18.3^{* * *}$ & $22.9 * * *$ & $19.5^{* * *}$ \\
\hline One or both spouses born Ireland & $13.8 * * *$ & $13.1 * * *$ & $20.5 * * *$ & $16.8^{* * *}$ \\
\hline One or both spouses born Great Britain & $8.2 * * *$ & $7.4^{* * *}$ & $8.5^{* * *}$ & $6.7^{* * *}$ \\
\hline One or both spouses born Canada & $7.5 * * *$ & $5.9 * * *$ & $9.2 * * *$ & $7.1 * * *$ \\
\hline One or both spouses other foreign born & $20.0 * * *$ & $19.4 * * *$ & $22.8 * * *$ & $19.4 * * *$ \\
\hline \multicolumn{5}{|l|}{ Couples' combined real estate wealth } \\
\hline None & $2.0 * * *$ & $2.5 * * *$ & $1.8 * * *$ & $2.2 * * *$ \\
\hline Moderate & ref. & ref. & ref. & ref. \\
\hline High & $-3.1 * * *$ & $-2.5 * * *$ & $-2.0 * * *$ & $-1.7 * * *$ \\
\hline \multicolumn{5}{|l|}{ Couples' combined personal estate wealth } \\
\hline None & & & -0.7 & 0.1 \\
\hline Moderate & & & ref. & ref. \\
\hline High & & & $-3.6 * * *$ & $-3.2 * * *$ \\
\hline \multicolumn{5}{|l|}{ Residence type } \\
\hline Rural & ref. & ref. & ref. & ref. \\
\hline Urban, population less than 10,000 & $-5.1 * * *$ & $-4.3 * * *$ & $-5.2 * * *$ & $-4.3 * * *$ \\
\hline Urban, $10,000-24,999$ & $-3.4 * * *$ & $-2.7 * *$ & $-3.3 * * *$ & $-2.6 * * *$ \\
\hline Urban, 25,000 - 99,999 & $-5.3 * * *$ & $-4.6 * * *$ & -1.4 & -0.4 \\
\hline Urban, 100,00 or more & -1.4 & -1.0 & $-3.8 * * *$ & $-2.5 * *$ \\
\hline \multicolumn{5}{|l|}{ Additional county-level control variables } \\
\hline Transportation & $-2.2 * * *$ & $-1.7 * * *$ & $-3.0 * * *$ & $-2.4 * * *$ \\
\hline School attendance, whites age 5-17 & $-25.3 * * *$ & $-21.7^{* * *}$ & $-15.7 * * *$ & $-13.8 * * *$ \\
\hline Proportion of labor force in manufacturing & -3.1 & -1.8 & $-12.1 * * *$ & $-11.4 * * *$ \\
\hline Average farm value per acre $(\ln )$ & 0.3 & 0.3 & $0.5 *$ & 0.4 \\
\hline Proportion of farm acres improved & $-15.3 * * *$ & $-13.0 * * *$ & $-16.3 * * *$ & $-14.3 * * *$ \\
\hline Proportion liberal/pietistic churches & $-5.9 * * *$ & $-4.9 * * *$ & $-12.8 * * *$ & $-10.6 * * *$ \\
\hline \multicolumn{5}{|l|}{ Bank availability } \\
\hline No banks in county & ref. & ref. & ref. & ref. \\
\hline 1 bank in county & $-1.9 * * *$ & $-1.5 * * *$ & $-1.5 * * *$ & $-1.1 * *$ \\
\hline 2 banks in county & $-1.7 * *$ & $-1.4^{*}$ & $-1.7 * * *$ & $-1.3 * *$ \\
\hline 3 banks in county & $-1.4 *$ & -0.8 & -0.7 & -0.4 \\
\hline 4 or more banks in county & $-2.0 * *$ & $-1.4 *$ & $-1.8 * * *$ & $-1.4 * *$ \\
\hline
\end{tabular}


Lagged Dependent Variable

Number children age $0-4$

Mean number of children age 0-4

Number of couples

R-square

Notes: All models employ state-level fixed effects. All independent variables are measured in the first census. See www.ipums.org for dicussion of occupation (OCC1950) and size of place (SIZEPL). See Tables 1-3 for definitions of countylevel variables. Control variables include women's age group and age differential of spouse (not shown). The dependent variable is the number of own ages $0-4$ in the household as identified by the IPUMS variable NCHLT5 and is measured in the second census. All coefficients were divided by the mean value of the dependent variable to increase comparability across models.

$*_{p}<0.05 ; * * p<0.01 ; * * * p<0.001$

$\begin{array}{rrrr}1.178 & 1.178 & 1.147 & 1.147 \\ 266,251 & 266,251 & 323,423 & 323,423 \\ 0.176 & 0.203 & 0.170 & 0.196\end{array}$

